Pace University

DigitalCommons@Pace

$11-30-2005$

\title{
Public Health and the Law: Responding to Terrorism and Other Public Health Emergencies in New York
}

Mark R. Shulman

Pace Law School

Follow this and additional works at: https://digitalcommons.pace.edu/lawfaculty

Part of the Health Law and Policy Commons

\section{Recommended Citation}

Shulman, Mark R., "Public Health and the Law: Responding to Terrorism and Other Public Health Emergencies in New York" (2005). Pace Law Faculty Publications. 311.

https://digitalcommons.pace.edu/lawfaculty/311

This Conference Proceeding is brought to you for free and open access by the School of Law at DigitalCommons@Pace. It has been accepted for inclusion in Pace Law Faculty Publications by an authorized administrator of DigitalCommons@Pace. For more information, please contact dheller2@law.pace.edu. 


\title{
Public Health and the Law: Responding to Terrorism
}

\author{
and \\ Other Public Health Emergencies \\ in New York
}

A Symposium devoted to public health law in a new era Cosponsored by Pace Law School,

The New York State Judicial Institute, and The Westchester County Department of Health 

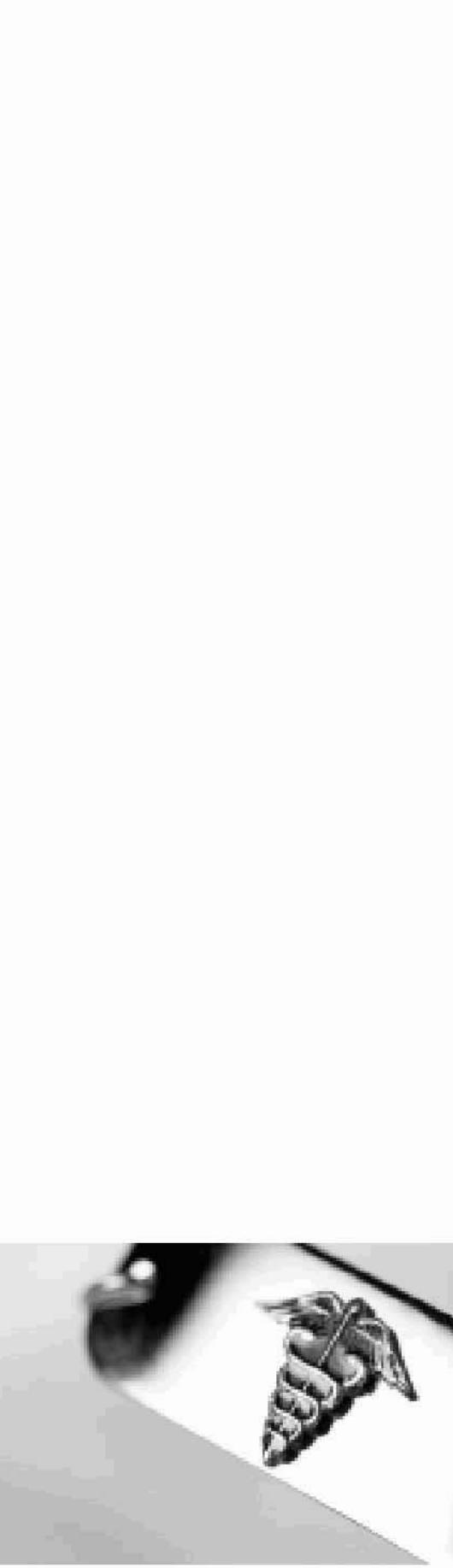


\section{Symposium AGENDA}

\section{Public Health and the Law: Responding to Terrorism and Other Public Health Emergencies in New York}

How would we react to an outbreak of SARS, avian flu, the Ebola virus, or smallpox? If Hurricane Katrina and other recent natural disasters teach us one lesson, it is that public health and security officials must plan in advance for catastrophes. Law and legal institutions must be thought through in light of contemporary threats in order to avoid the chaos that plagued New Orleans. Over the past several years, New Yorkers have faced several similar threats to health and safety. From intentional tragedies such as $9 / 11$ and the anthrax attacks, to accidents and naturally occurring disasters such as the 2003 blackout and the SARS outbreak, New Yorkers have considerable experience in reacting to large-scale emergencies, but these laws and institutions have not been updated to reflect these experiences. Even now, the specter looms as avian influenza threatens to become a global pandemic.

Each of those occurrences has the potential to affect the health of large numbers of people, and governments must lead the response to them. Law, politics, and custom determine the respective responsibilities and formal relationships of the various levels of government (federal, state, and local) in the event of a public health emergency. Public health officials have historical experience and police power at their disposal, but the legal authorities underlying these powers are relics of a time before the era of judicially recognized individual rights, jet travel, and the Internet. Experts in both the legal and the public health fields are increasingly recognizing the need to modernize or reshape statutes, regulations, and public health practices to resolve tensions between the demands of public health and the legitimate claims of individuals in a democratic society.

This symposium focuses on understanding, evaluating, and developing suggestions for improving legal aspects of the responses by New York's government entities to public health emergencies. How is New York legally prepared to respond to a public health emergency, and what, if anything should be done to improve the response capacity of its governments? Can we avoid the mistakes of Louisiana? Should we wait for the federal government to decide its own policies? These questions are not only timely but also address some of the most significant tensions inherent in government's assumption of increased powers in an emergency: those arising from its need to prevent the spread of disease through the control and protection of persons, and the use, regulation, and seizure of property.

New York has traditionally been a leader in the field of public health. Drawing on a wealth of experience, a robust set of laws, and some of the nation's leading practitioners and academics, New York State serves naturally as a laboratory for progressive legislation and institution building. The objective of this symposium is to build on that expertise to help generate better laws and practices in this critical field. 


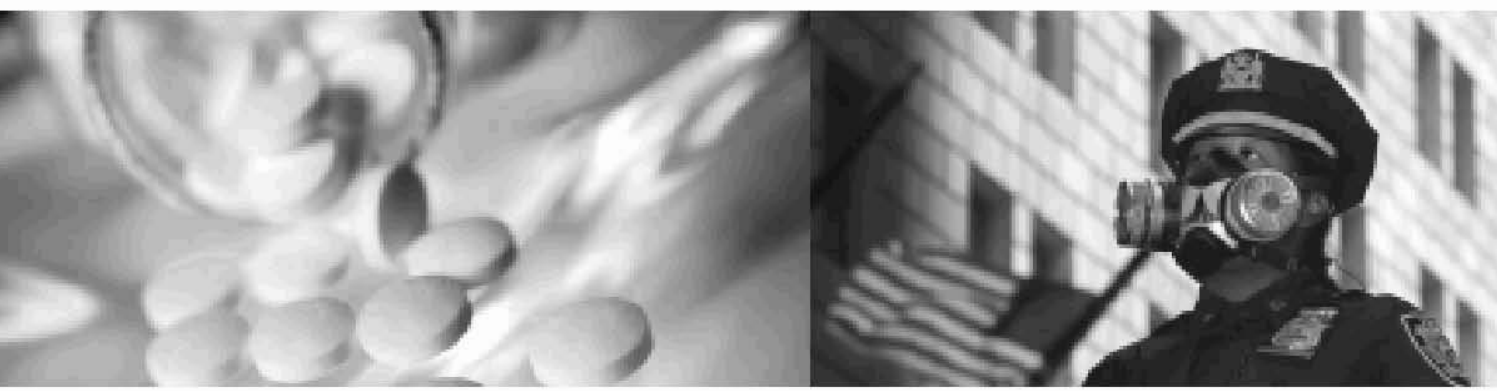




\title{
SYMPOSIUM REPORT
}

\author{
MARK R. SHULMAN
}

Scientists have long forecast the appearance of an influenza virus capable of infecting $40 \%$ of the world's human population and killing unimaginable numbers. Recently, a new strain, H5N1 avian influenza, has shown all the earmarks of becoming that disease. Until now, it has largely been confined to certain bird species, but that may be changing.

\section{Laurie Garrett ${ }^{1}$}

With the support of the Alfred P. Sloan Foundation, the November 30, 2005, symposium on Public Health and the Law: Responding to Terrorism and Other Public Health Emergencies in New York was a great success. The symposium brought together nearly 100 experts from New York and around the nation to discuss threats to the state's public health, the institutions and laws designed to prepare for and meet these threats, and the legislation proposed to improve New York's response. Participants included health care professionals, public health experts, lawyers, lawmakers, executives, academics, judges, and first responders.

Pace Law School Professor Linda Fentiman, Westchester County Commissioner of Health Joshua Lipsman, and Pace's Assistant Dean for Graduate Programs and International Affiliations Mark R. Shulman cochaired this symposium convened at the New York State Judicial Institute. A White Paper written by Dr. Lipsman (and included in this report) was distributed to each participant along with a binder of supporting articles and other resources.

The entire symposium can be viewed for free via webcast at the symposium Web site: http://library.law.pace.edu/research/public_health_emergencies.html. ${ }^{2}$

Irma Russell gave the conference charge, urging the participants to work to develop ways to protect society against public health threats - and from loss of vital civil liberties. Too frequently, Professor Russell argued, security and liberty are weighed against one another; she charged the conference to examine ways to improve both without upsetting the complex web of safety and security that Americans have developed over the centuries. Professor Russell's comments are detailed and expanded upon in her thoughtful essay published for the first time as part of this report.

Joshua Lipsman then introduced the specific issues that the symposium would address. Dr. Lipsman discussed the range of threats to public health - principally bioterrorism and such infectious diseases as the avian flu - and to civil liberties. He explained the broad range of institutions upon which public health relies in ordinary times and which are stressed during emergencies. These include hospitals, police, and the fire and public health departments. He noted that these critical institutions generally lack the surge capacity that a public health emergency would demand. Likewise, Dr. Lipsman noted that our "legal tools are rusty and partially outdated" but that a variety of legal reforms have been introduced around the country, each intended to provide greater authority and coordination in time of public health emergencies. The leading piece of legislation proposed in New York, a version of the Model State Emergency Health Powers Act (MSEHPA), however strong and coherent it is, contains elements that give the governor great authority to act 
with insufficient controls for civil liberties and inadequate appreciation for the roles that local health officials inevitably play in an emergency. Dr. Lipsman proposed taking another look at the legislation in light of the more recent Turning Point Model Act - a piece of model legislation drafted by the same team after encountering various arguments against their original act. To the extent that the symposium achieved some consensus, it favored the Turning Point as a more appropriate model for meeting the needs of New York State.

Westchester County Executive Andrew Spano (pictured here with Dr. Lipsman) emphasized the need for an articulated ladder of executive authority during emergencies. Mr. Spano spoke with par-

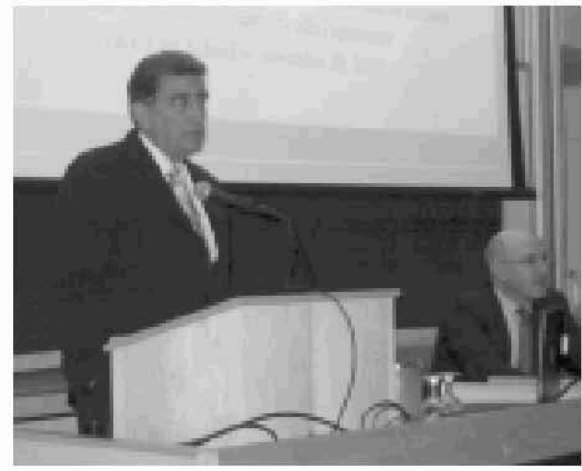
ticular urgency that day, as he went directly from the symposium to a county-wide emergency response exercise at the Indian Point nuclear power facility - a major reactor set amidst a densely populated suburban area. One in 12 Americans lives within 50 miles of Indian Point, which is situated in the independent hamlet of Buchanan. Mr. Spano noted that under the existing legal regime mayors, county executives and the governor may each declare states of emergency for their own jurisdictions and that no one declaration takes precedence over another. Consequently, the county cannot reallocate the resources of a municipality. A similar lack of a designated point person results in chaotic lines of authority such as those that crippled Louisiana during the 2005 response to Hurricane Katrina. Mr. Spano proposed that local and municipal executives should manage the response to an emergency unless and until the county executive steps in and declares his own state of emergency. Likewise, the county executive would direct the response unless and until the governor declares his own state of emergency. Finally, the law should be clarified to allow the President of the United States to take control and preempt state authorities when necessary. At this point, Joseph E. Bruno, Commissioner of New York City's Office of Emergency Management, pointed out that New York City does have clear lines of command and agreed with Mr. Spano that the National Incident Management System could work better with Westchester or other counties to bring them up to the level of the city.

In a related discussion, Barry Steinhardt of the American Civil Liberties Union agreed that clarification of lines of authority and responsibility during an emergency would be helpful. Mr. Steinhardt was careful to reserve issues about the circumstances justifying such declarations and the powers they would confer. He noted that the MSEHPA, if enacted in New York, would give too much unfettered authority to the governor during any situation that the governor deems an emergency. He supported modernizing the public health laws with the intention to improve their effectiveness while ensuring that they conform to contemporary notions of civil liberties. Reminding the audience that the enemy is a pathogen, not people, he noted that mass quarantines do not work. As an example, he pointed out that when China declared a quarantine to contain SARS in the spring of 2003, nearly a quarter of a million people fled the affected city before the quarantine could be enforced.

Other speakers discussed current New York public health law, and addressed the question of whether it should to be changed to address new types of emergencies, as well as such traditional public health concerns as outbreaks of food-borne diseases and contaminated drinking water. Some 
speakers expressed concern that the intense focus on responding to a bioterrorist attack, such as anthrax or smallpox, was diverting attention from public health problems that were more likely to occur. For instance, Victor W. Sidel, the Distinguished University Professor of Social Medicine at Montefiore Medical Center and Albert Einstein College of Medicine, noted that responses to public health emergencies must be designed in an appropriately broad context. Every dollar spent preparing for an act that may or may not occur seems to be spent at the expense of efforts to avert or mitigate the impact of existing public health hazards such as guns, AIDS, ordinary flu, tuberculosis, and chemical spills that are killing Americans each day. In short, Dr. Sidel made the argument for threat assessments and responses based on epidemiology and public health analysis rather than on panicky reactions to more dramatic threats.

Since shortly after $9 / 11 / 01$, the New York State Legislature has been considering adoption of a version of the MSEHPA that "grants public health powers to state and local public health authorities to ensure strong, effective, and timely planning, prevention, and response mechanisms to public health emergencies (including bioterrorism) while also respecting individual rights." Benjamin Berkman, a scholar at the Georgetown University Law Center and the Center for Law and the Public's Health, which produced the MSEHPA as well as the newer Turning Point Model Act, explained the value of the MSEHPA as a model but conceded that it might not be needed in New York. Critics of the MSEHPA, such as the New York Civil Liberties Union, have argued: "The Act defines 'public health emergency' in a manner that is overly broad, and fails to clarify sufficiently the circumstances that would justify the declaration of such an emergency." ${ }^{3}$

Richard Gottfried, chair of the New York State Assembly Health Committee, would support the MSEHPA. However, he provided key insights why the state would not be able to enact it. He called instead for incremental improvements to the current law instead. Likewise, while several symposium participants endorsed the Turning Point Model Act, they acknowledged that it too was unlikely to be adopted in New York.

One of the MSEHPA's principal sponsors in New York, State Senator Michael Balboni, agreed that New York does not need the remedies the MSEHPA proposes. Senator Balboni explained that he had introduced it only to draw attention to deficiencies in New York's overall level of preparedness. (In the photograph above, Sen. Balboni is pictured at right, with Assemblyman Gottfried and Dean Shulman at the far left).

Senator Balboni continued to express his belief that humanity is at the beginning of a world health

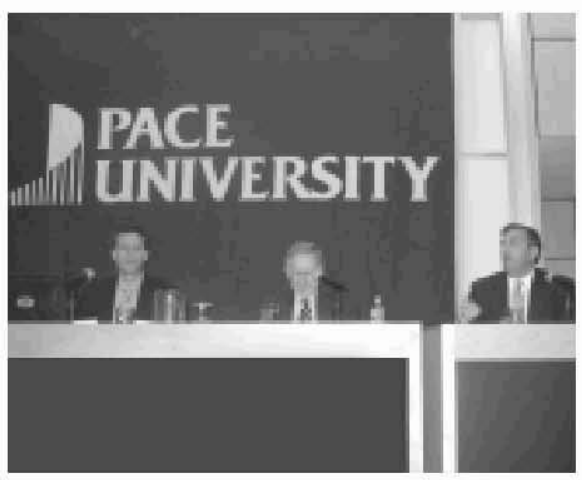
crisis and that New York's level of preparedness is woefully inadequate to the challenges it will face. As he noted when he introduced the MSEHPA in the New York Senate, "This state faces a threat to its public health, safety, and security that has never been faced before. The threat of bioterrorism requires that government respond with extraordinary powers. Because the state is responsible for the health, safety, and security of its people, it must be able to respond rapidly and effectively to public health threats. This legislation allows the governor to act decisively in the event of a bioterrorist attack to secure the safety, security, and health of the public." ${ }^{4}$ In his symposium 


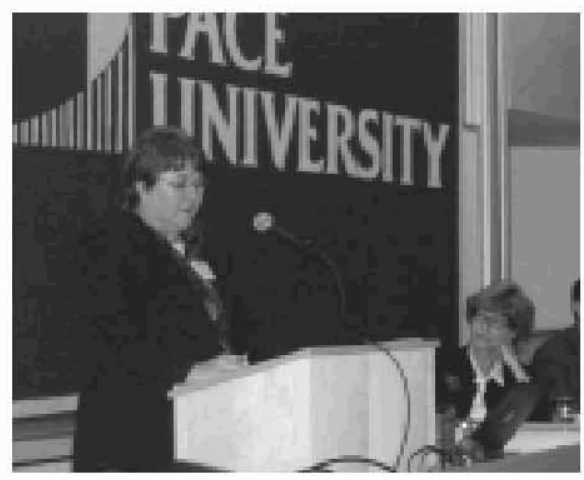

comments, however, it became clear that Senator Balboni is less concerned by a lack of legal capacity than by the inadequacy of the infrastructure and about bottlenecks in the provisioning of emergency health care - particularly at the distribution points. He urged a dramatic increase in the number of hospital beds, health care providers, and other facilities that would give the state surge capacity to meet a crisis. ${ }^{5} \mathrm{He}$ also proposed that hospitals develop cogeneration sources that will enable them to function when the electric power grid fails. To this point, Brian Nickerson, director of the Pace University Edwin G. Michaelian Institute, added that hospitals will face a particularly urgent need for surge capacity in critical care and isolation units.

David Keepnews, Director of the Office of Policy Development for the New York Academy of Medicine, agreed on the significance of the distinction between authority and capacity. For his part, Dr. Keepnews proposed increased public and expert participation in the lawmaking, to ensure meaningful and timely input from those who are best positioned to determine the emergency needs. He suggested that these providers will call - as Senator Balboni does - for increasing capacity and for leaving statutory authority little or unchanged.

Linda Chezem of the University of Indiana and the National Institute on Alcohol Abuse and Alcoholism emphasized that the training of judges is essential now to ensure that they will be prepared to adjudicate public health emergencies when they arise. Judge Chezem has been writing bench books on public health emergencies for several years, providing judges with model orders that will meet exigencies while adhering to Constitutional requirements. Without this kind of advance planning, emergencies may overwhelm the judicial system's ability to provide sensible jurisprudence at a critical juncture.

Like Judge Chezem, most participants emphasized the importance of articulating in advance the process that is due in order to protect individual liberties while preserving the public health. On that point, however, Barbara Asheld, an Associate Attorney in the New York State Department of Health, and Robert Burhans, Director of the New York State Office of Public Health, Preparedness and Response to Bioterrorism, were more sanguine. They argued that health officials and their lawyers had already addressed these issues and were prepared to face emergencies. Ms Asheld is pictured above left with Professor Fentiman. Nassau County Health Commissioner David Ackman noted that each health department has been tasked to improve its ability to investigate, mitigate, and communicate in the event of a public health emergency. Dr. Ackman reported that great strides have been made on each of these fronts since 2001. And yet, he concluded, there remains much to be done because a pandemic influenza would quickly overwhelm the public health apparatus. Like several other speakers, he focused on the need to involve physicians and other health care professionals in private practice in planning for emergencies, in order to maximize the effectiveness of their volunteer efforts. He also added to Dr. Sidel's list of public health issues such chronic problems as obesity, substance abuse, and violence - each of which leads to early and preventable deaths each day. 
While the symposium did not generate any concrete consensus, virtually everyone agreed that the MSEHPA does not meet New York's needs. Few would push for increasing the legal authority of the govemor. There is, however, room for improving the system by which the executive relates to other authorities such as local governments and the judiciary. Most participants emphasized the importance of fortifying the State's public health infrastructure to ensure that the institutional capacity is in place and that the delivery systems function effectively.

\section{Public Health and Safety: Terrorism and OTher Dangers IRMAS. RUSSELL ${ }^{5}$}

Dangers to public health and safely range from natural disasters such as Hurricane Katrina and avian flu to the man-made theat of terrorism. Such hreats present challenges for government in its role as a protector of public safety and the protector of individual freedoms, putting the role of government at the heart of the debate on public health and safety. Indeed, modem threats to public safety create a crucible for testing the complex relationship between government and citizens in dramatic situations. This essay does not categorize or discuss all types of threats to public health. Rather, it focuses on terrorism, a context that provides dramatic examples of threats to public health and personal liberties and raises issues inherent in areas of challenges to public health.

On September 11, 2001, after the attacks on the World Trade Center and the Pentagon, President George Bush framed the challenge: "Freedom itself was attacked this morning," President Bush has also emphasized the importance of protecting the safety of the public, often stating that his first priority as president is to protect the American people. In the wake of the terrorist attacks of September 11, the U.S. Congress passed the Uniting and Strengthening America by Providing Appropriate Tools Required to Intercept and Obstruct Terrorism Act of $2001^{9}$ (referred to as the "PATRIOT Act" or "the Act"). Among other things the Act expanded the power of the government to engage in electronic surveillance of international terrorist activities inside the United States. ${ }^{11}$ Since that time, the Iraq war and other actions have raised new questions about the responsibility of govemment to protect people's safety and freedom. Should the government conduct searches without warrants? Is torture justified as part of the government's effort to protect public safety? Do the inherent powers of the president include the right to authorize domestic surveillance? The complexity of such questions and the relationship between govermment and citizens has fascinated courts and scholars throughout the history of this conntry, and the tension between issues of public health and individual liberty is well-established ${ }^{12}$ In his dissent in Meachim v. Funo, Justice John Paul Stevens analyzed the foundation of liberty. Rejecting the majority's assertion that the liberty interest may "originate in the Constitution," or have "its roots in state law,"13 Justice Stevens reasoned that rights and liberties predate govermment.

If a man were a creature of the state, the analysis would be correct. But neither the Bill of Rights nor the laws of sovereign States create the liberty which the Due Process Clause protects. .. . [L]aw is essential to the exercise and enjoyment of individual liberty in a complex society. Bat it is not the source of liberty, and surely not the exclusive source. I had thought it self-evident that all men were endowed by their Creator with liberty as one of the cardinal unalienable rights. It is that basic freedom which the Due Process Clause protects. ${ }^{14}$

Justice Stevens' reference to the self-evident nature of liberty calls to mind the Declaration of 
Independence and its recognition of the inalienable nature of personal freedoms. President Bush has also emphasized the centrality of liberty and freedom to democracy. Shortly after the attack on the World Trade Center he stated: "We are a country awakened to danger and called to defend freedom ... As long as the United States of America is determined and strong, this will not be an age of terror. This will be an age of liberty here and across the world." 15

The slogan "Freedom is not free" has been a call to ams. The profound truth the slogan announces reaches beyond a justification for the war, however. Phrased in the singular form, the statement is pure abstraction. Nevertheless, it raises provocative questions, including the question of whether the costs of freedom should be paid by others. The answer to this question seems to depend on the nature of the threat. In extreme circumstances, self-defense may be justified; an invasion requires a military defense. Threats to individual liberties, either from governmental action - the risk addressed by the Bill of Rights - or from terrorism, present a more complicated cost formula. Most people recognize that nothing of value is free and that individual freedoms, the central tradition in our national ethic, carry great costs. The concepts of liberty and freedom embody both realities and abstractions. Without personal liberties, the word "freedom" has little content other than as an abstraction. Traditions of democracy soundly reject a trade-off of individual freedoms for a general abstraction of freedom, and compromises of civil liberties for a general concept of "freedom" are radically out of step with the history and legal traditions of the nation.

Freedoms are not free. The plural form of this statement focuses attention on the reality of the costs of individnal liberties. Individual liberties, snch as the freedoms of speech, association, religion, privacy, and protections against criminal prosecution cannot be protected by the cost of military action. Freedoms embodied in real rights rather than simple abstractions camot be bonght by risking, others. They are paid for in the day to day acceptance of those same freedoms for others within sociey. Perhaps it is all too human to want our freedoms while fearing the exercise of those same freedoms by others - particularly when the others are marked by their "otherness." Nevertheless, inherent in some freedons is the fact that ensuring one person's freedoms requires ensuring the same freedoms for others, in practical and everyday reality rather than as abstractions. Thus, while protection of our privacy makes us safe it seems also to put us at risk because it ensures the privacy of others.

We secure personal freedoms for ourselves by securing the same freedoms for others. My right to privacy is secure only when the same right is afforded others -- some of whom I may distrust. Recognition of the inextricability of some costs and benefits finds voice in another slogan: "virtue is its own reward." According to this logic, some abstractions and some costs defy externalization. The costs of personal freedoms are integral to the exercise of the freedoms themselves. Outsourcing of the cost is not possible. The cost of freedoms resides in the exercise of freedom, within an internal calculus not susceptible to easy articulation or simple payment. The risks of fieedoms are inherent in the freedoms themselves. Just as virtue contains its own costs and rewards, freedoms incur costs in their exercise. Such a calculus drives toward the conclusion that the full cost of freedoms cannot be paid on foreign shores.

The terrorist attacks on September 11, 2001, challenged the United States in unprecedented ways, raising concens about public safety to new levels. While nnprecedented risks gives rise to an argument that unprecedented responses are necessary, ${ }^{15}$ threats to public health and safety are not the only threats that deserve analysis in a democracy. Moreover, a simplistic cost-benefit approach to the tension between physical safety and civil liberties entails additional risks that require assessment. 
Whether terrorism and the war on terrotism have altered irrevocably the American tradition of individual freedoms depends on what happens next. Terrorism and other theats to public health must not be ignored. Nevertheless, an analysis that capitulates to fear carries its own risks. Treating the protection of society and civil liberties of individuals as counterbalanced factors undervalues not only individual civil liberties but also the societal value of civil liberties. Democracy promises protection of individual liberties, benefiting individuals and, additionally, society as a whole. Individual liberties provide a structure within which the government meets its responsibility to the public, protecting society one person at a time. In this sense, individual liberties are not merely individual because they further the cumulative goal of protecting society by protecting individual rights. The pay-off for society as a whole is a benefit for each individual within sociely.

The United States faces persistent and growing tensions regarding the appropriate relationship of protections of the public's safety and protections of civil liberties. The tisks of terrotism are real, and the risks that accompany the diminution of individual freedoms are also real. They are the same risks that motivated the founders to adopt the Bill of Rights and to protect civil liberties against. government infringement. The point of this assessment is not to mimimize the gravity of threats to public safety. Rather, it suggests that minimizing the importance of personal freedoms presents discrete dangers that should not be ignored. Fundamental principles of democracy require discussion and debate in the public arena. ${ }^{18}$ The process of debate and public input is essential to maintaining the public trust in the govermment's ability to regulate risks effectively and the reality of the government's ability to so regulate. Fears naturally lead to a desire to minimize risks, whether they arise from natural disasters, terrorism, or other threats. As a society, we must consider both threats to our lives and threats to our way of life, however. Most important, the issues of government powers in a democracy require discussion and debate in the public arena. The Pace Law School Symposium on Public Health Emergencies and the Law: Responding to Teryorism and Other Public Health Emergencres in New York advances this important work.

1 Laurie Garrett, "The Next Pandemic" Foreign Affairs (July/August 2005) 3.

${ }^{2}$ For Continuing Legal Education credit for watching the webcast, contact Kathleen Carlisle at KCarlisle law pace edu.

3 Testimony of Robert Perry on Behalf of the New York Civil Liberties Union before the Assembly Standing Committe on Health and the Assembly Standing Committee on Codes Concerning the Model State Emergency Health Powers Act (March 14, 2002). See www.nyclu.orgleg_modelpha_03152.html.

4 Senator Michael A.L. Baboni, "New York State Senate Introducer's Memorandum in Support" (2005).

5 Among numerous articles reporting the breathtaking lack of readiness for an emergeney, see "Experts Say Medical Ventilators Are in Short Supply in Event of Bird Flu Pandemic," New York Times (March 12, 2006 ) A24.

6 Professor of Law, University of Tulsa College of Law, Visiting Professor of Law, Pace Law School. The author thanks Linda Pope and Professors Marguerite Chapman, David Harris, and Ann Powers for comments on earlier drafts of this work. She thanks Eric Grille, Charles Holliday, and Barbara Leiterman for their research assistance.

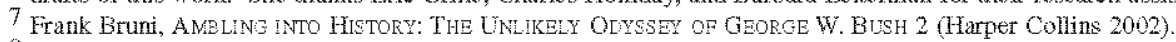

8 Fact Sheet: Safeguarding America: President Bush Signs Patriot Act Reauthorization, (March 9, 2006) availabile at http:/www whitehouse gov/news/releases/2006/03/20060309-7.html (visited 3/12/2006).

9 Pub. L. No, 107-56, 115 Stat. 272 (2001).

10 See Uniting and Strengthening Anerica by Ptoviding Appropriate Tools Required to Intercept and obstruct Terrorism (USA PATRIOT ACT) Act of 2001, Fub. L. No. 107.56, \$§ 201-16, 115 Stät. 272, 278-90 (collified as amended in scattered sections of U.S.C.).

11 18 U.S.C. $\$ 2516(2006)$.

12 See Wong Wat y. Wirtanson, 103 F. 1 (N.D. Cal. 1000) (finding quarantine of all Chinese or Asiatic persons until vaccinated unconstitutional absent definitive and compelling evidence of high likelihood of contamination); 
Jacobson v. Massachisetis, 197 U.S. 11 (1905) (finding mandatory vaccination within state police power so long as community is in imminent danger and means used are not arbitrary or unreasonable); Rhe a v. Boand of Ediucation, 171 N.W. 103 (N.D. 1919) (holding unconstitutional prerequisite of vaccination for public school attendance absent existing dangerous condition or express legislative authority).

13 Meachum v. Fano, 427 U.S. 215, 230 (1976) (Stevens, J., dissenting) (citations omitted).

$14 \mathrm{Id}$.

15 Frank Bruni, Ambing into Higtory: The Unlikely Odyssey of Gerge W. Bush 11 (Harper Collins 2no2).

16 Although early human communities may not have articulated the danger as one of world annihilation, people in plague-ridden cities may well have experienced fear at precisely this level. Indeed, some ancient civilizations perished in catastrophic natural disasters and hostile attacks, leaving lessons on preparedness as well as mysteries.

17 An article reporting China's new guarantees of protection for criminal defendants made this point in the specific context of procedural protections for the accused. It identified a "fundamental contradiction" in China's goals. While China's leaders want law to "enhance, not erode, government power," they want the Chinese pe ople "to trust. the legal system because public support is essential in ensuring social stability." Jim Yardley, "Rule by Law: A Father's Quest, Desperate Search for Justice: One Man vs. China," Now York Tirses Nov 12, 2005, A1 (noting that Chinese leaders have "shown little inclination to replace a system that guarantees convictions with one that guarantees the rights of the accused").

18 The Symposium on Public Health Energencies held at Pace Law School considered whether adoption of the Model State Emergency Health Powers Act (MSEHPA) is a strategic gain in preparing for public emergencies. Whether the MSEHPA would advance the cause of public protection in New York depends on the current system in place and the legislative judgment regarding the effectiveness of the MSEHPA in comparison with that current system. 


\section{SYMPOSTUM WhTt PAPER}

by Joshua Lipsman

\section{Introduction}

In the first years of this new century, New Yorkers have become acutely aware of the great hazards that the world can bring. From intentional tragedies such as the destruction of the World Trade Center towers on September 11, 2001, and the bioterrorism of the anthrax attacks that fall, to accidents and naturally occurring disasters such as the blackont of Angust 2003 and the outbreak of SARS that winter, residents of New York now are all too familiar with large-scale emergencies. Even as this paper is written, the specter looms of a global pandemic of avian influenza.

All of those occurrences were either threatened or actual public health emergencies, in that they have the potential to affect the health of large numbers of people and it is in large part the responsibility of government entities to respond to them. In New York, government entities include municipal, county, and state governments, all of which may have roles to play in a public health emergency. Law, politics, and custom determine the respective responsibilities and formal relationships of the various levels of government in a public health emergency.

This paper focnses on legal aspects of the responses by New York's government entities to public health emergencies. The questions asked are: How is New York legally prepared to respond to a public health emergency, and what, if anything, should be done to improve the response capacity of New York's governments? These questions are not only timely but also address some of the most significant tensions inherent in government's assumption of increased powers in a public health emergency: those arising from its need to prevent the spread of disease through the control and protection of persons, and the use, regulation and seizure of property.

Such tensions arise because the federal and state constitutions give us rights that can be infringed upon by government only in extraordinary circumstances. The United States Constitution assures that "[n] person shall be ... deprived of life, liberty, or property, without due process of law"; nor shall private property be taken for public use, without just compensation." ${ }^{1}$ The Fourteenth Amendment applies the rights of due process and equal protection to state actions. ${ }^{2}$ The New York State Constitution promises that "[n]o person shall be deprived of life, liberty or property without of law ${ }^{3}$ [and p]rivate property shall not be taken for public use without just compensation." " This paper premises its analyses on these constitutionally guaranteed liberties.

Part II of the paper focuses on the law in New York for dealing with public health emergencies. Part III considers the Model State Emergency Health Powers Act ("the MSEHPA"), model legislation prepared by the Center for Law and the Public's Health at Georgetown and Johns Hopkins Universities. Part IV offers assessments of the law in New York and a proposed New York version of the MSEHPA. PartV concludes with some steps to enhance legal preparedness for public health emergencies in New York.

\section{The Law In New York For Responding To Public Health Emergencies}

Statutory law relating to civil liberties issues in public health emergency situations is limited. Some federal authority with regard to the control of communicable diseases is vested in the Surgeon General, ${ }^{6}$ but for the most part states have this responsibility. In New York, relevant law is found in several places. The Public Health Law has no specific section on poblic health emergencies, but 
applicable provisions are found in sections on nuisances ${ }^{7}$ and control of acute communicable diseases, ${ }^{8}$ complemented by the State Sanitary Code. Relevant Public Health Law statutes are few and no other regulations than the Sanitary Code periain.

The Defense Emergency Act of $1951^{10}$ is the most comprehensive legislation to address mass emergencies, including public health emergencies. It has no associated pertinent administrative rules and regulations oher than a recent Executive Order that implicates no constitutional issues. ${ }^{11}$ State and Local Natural and Man-Made Disaster Preparedness legislation ${ }^{12}$ passed in 1978 adds administrative detail to the state's planning and response authority; it has no associated regulations.

Disposative case law relating to the control of persons or property in a public health emergency sitvation also is limited.

\section{A. Basic New York Public Health Law}

Under New York Public Health Law for the regulation of nuisances, the State Health Commissioner has "all necessary powers to make investigations and examinations into nuisances, or questions affecting the security of life and health in any locality:"13 This authority may be delegated to local health officers, ${ }^{14}$ who under the direction of the "local board of health shall order the suppression and removal of all nuisances and conditions detrimental to life and health found to exist within the health district." is

New York Public Health Law for the control of acute communicable diseases declares that "[e]very local board of health and every health officer shall guard against the introduction of such communicable diseases as are designated in the sanitary code, by the exercise of proper and vigilant medical inspection and control of all persons and things infected with or exposed to such diseases." 15 Boards of health and health officers are authorized to "provide for care and isolation of cases of communicable disease in a hospital or elsewhere when necessary for protection of the public health."17 The law does not have any generic provisions for vaccination or treatment though there are provisions for specific immunizations of students to attend educational institutions. ${ }^{18}$

Any "person having knowledge of an individual affected with any disease presumably communicable, [has the duty] to report immediately the name and address of such person to the ... health officer."19 The local health officer must investigate the circumstances surrounding reports that an individual is sick or infected with a communicable disease "and is unable or unwilling to conduct himself and to live in such a manner as not to expose members of his family or household or other persons ... to danger of infection." ${ }^{20}$ If the health officer finds that "a person so afflicted is a menace to others," the person before a magistrate who, after notice and hearing, "if satisfied that ... the afflicted person is a source of danger to others, may commit the said person to [a] hospital or institution."22

Heal th officials have a right of entrance and inspection "to any house, building, vessel, or other premises ... in the discharge of [their] official duties:"23. A health officer may direct that rooms and effects be cleansed and disinfected; articles that cannot be disinfected may be destroyed. ${ }^{24}$

The foregoing provisions are the only ones that apply to prevention and response to communicable diseases generally, and even those provisions require that a new disease be added to the State Sanitary Code either before or shorly after the law is enforced. ${ }^{25}$ Public Health Law provisions for the control of specific diseases would not apply in the event of a public health emergency caused by a different microorganism. ${ }^{26}$ 


\section{B. The New York State Defense Emergency Act}

In 1951, the New York State Legislature declared that "there exists a serious danger that this state will be subjected to enemy attack, including attack by atomic bombs or other radiological weapons." 27 In passing the New York State Defense Emergency Act " "the Act") in response to perceived nuclear theats, the Legislature declared that "[i]t is the purpose of this legislation to meet these dangers and problems with the least possible interference with the existing division of the powers of the government and the least possible infringement of the liberties of the people, including the freedom of speech, press, and assembly." 28

The Act "established a broad coordinated civil defense program." "2y One of the Act's key provisions is the creation of the State Civil Defense Commission in the govemor"s office. The Commission has extensive powers and duties, including authority to plan and to promulgate wide-ranging regulations. ${ }^{31}$

During an attack, defined as "[a]ny attack, actual or imminent ... by an enemy or a foreign nation ... causing, or which may cause, substantial damage or injury to civilian property or persons ...by the use of bombs, shellfire, or nuclear, radiological, chemical, bacteriological, or biological means," the Civil Defense Commission has even broader power, to commandeer personnel and materiel, both public and private." Also during an attack that "jeopardizes the safety or the health of the people," the Act allows the Commission to permit counties and cities, to "compel the evacuation" of people in the name of safety, "control all pedestrian and vehicular traffic, transportation and communication facilities and public utilities, [and] take, use, or destroy real or personal property and impress persons into service for" the Act's civil defense purposes. ${ }^{34}$

The Act also allows counties and the cities within counties to form consolidated offices of civil defense $^{35}$ and permits "wwo or more political subdivisions of the state [to] enter into mutual aid agreements [in which s] tate agencies [also] may participate."36

The Act permits the governor to "designate any area in the state ... as an emergency health and sanitation area and fix the bonndaries thereof" whenever "an emergency exists as the result of attack, or [ if,] as a result of conditions created directy or indirectly by the defense effort, insufficient or inadequate medical or health personnel or facilities are available in any area." ${ }^{27}$ After such a designation,

it shall be the duty of the local board ... of healh ... to make and enforce rules and regulations consistent with the provisions of the public health law (a) to prevent of limit the introduction or spread of any contagious or infectious disease and (b) 10 protect the public health within the area. ${ }^{3 .}$

The Act does not explain what "consistent with the provisions of the public health law" means, leaving open the possibility of both varied and contested applications of the Public Health Law in an attack situation.

The Act confers broad immunity from liability on the state and state actors acting in good faith, even in the event of death, personal injury or property damage. ${ }^{20}$

\section{State And Local Natural And Man-Made Disaster Preparedness Legislation}

In 1978, the New York State Legislature enacted State and Local Natural and Man-Made Disaster 
Preparedness legislation ("the legislation"). ${ }^{40}$ The Legislature noted that "the state must give leadership and direction to this important task of establishing an emergency disaster preparedness program, [but also found] that without local disaster planning, no state disaster program can be fully effective," since local governments are "the first line of defense in times of disaster." The Legislature further indicated that the purpose of the legislation was to empower local chief executives to "develop... and implement... disaster preparedness programs".43 and to coordinate "state and local natural disaster and emergency response functions.",44

The legislation creates "a disaster preparedness commission" high-level public and private officials that meets twice a year" to "prepare state disaster preparedness plans" that are to be reviewed and reported upon to the governor annually. "The Disaster Preparedness Commission serves in an executive capacity and must "coordinate" and "integrate" its work with that of the more administrative Civil Defense Commission. ${ }^{48}$

State disaster preparedness plans must include provisions for "disaster prevention[,] response[, and] recovery." The legislation also authorizes counties to prepare "local disaster preparedness plans" with similar provisions. ${ }^{50}$ In contrast with the Defense Emergency Act, the legislation contains no language authorizing any disaster preparedness plans to provide for exercising control over persons or private property.

"[F]ollowing the declaration of a state disaster emergency" the Disaster Preparedness Commission is to "direct state disaster operations and coordinate state [with local] disaster operations" and is authorized to create "a temporary organization in the disaster area to provide for integration and coordination of efforts among the various federal, state, municipal, and private agencies involved." 52 The Commission "may, with the approval of the governor, ditect the temporary organization to assume direction of the local disaster operations of [a] municipality ... unable to manage [its own] local disaster operations," ${ }^{\text {s3 }}$

The legislation allows the governor ${ }^{54}$ or a local chief executive to declare a local state of emergency, during which the legislation grants the chief executive many of the powers conferred by the Defense Emergency Act, though the legislation offers more specifics and detail ${ }^{55}$ In a declared emergency, only the governor is authorized to request federal assistance. ${ }^{56}$ During such an emergency, the governor may suspend state and local laws, subject to the state and federal constitutions and specified restrictions. ${ }^{57}$

\section{Case Law}

Federal and state case law regarding the control of persons and property applies in New York, though case law applicable to civil liberties issues in public health emergency situations generally is limited. ${ }^{58}$ A particularly important federal case from a century ago, Jacobson 1. Masachusets, ${ }^{55}$ is known for its confimation of the reasonable use of state police power to protect public health and safety. The Jacobson plaintiff challenged his compulsory participation in the state's smallpox vaccination program as unreasonable, arbitrary and oppressive. ${ }^{50}$ Affirming the Massachusetts Supreme Judicial Court holding that the program was constitutional, the Supreme Court held that

the liberty secured by the Constitution ... does not import an absolute right in each person to be, at all times and in all circumstances, wholly freed from restraint. [I]t as a fundamental principle that "persons and property are sub- 
jected to all kinds of [reasonable] restraints and burdens, in order to secure the general comfort, health, and prosperity of the State... ${ }^{6}$

A contemporaneous New York case relied on by the Jacobsont Cont, Vemetster 1 . White, ${ }^{62}$ upheld mandatory smallpox vaccination for school entry. Plaintiff father appealed a lower court's denial of an order for the school to admit his unvaccinated child, which conflicted with school board regulations. Noting that "[w]hen the sole object and general tendency of legislation is to promote the public health, there is no invasion of the Constitution, even if the enforcement of the law interferes to some extent with liberty or property," 53 the Court of Appeals held that "[i]f vaccination strongly tends to prevent the transmission or spread of this disease, it logically follows that children may be refused admission to the public schools until they have been vaccinated. ${ }^{934}$

In th re Smith ${ }^{65}$ plaintiffs challenged their involuntary quarantine during an outbreak of smallpox in Brooklyn. The Smith plaintiffs had a business carying furniture and household effects in the city's "worst infected district." The City of Brooklyn Health Commissioner asserted that they were "unusually exposed to ... contagion" and required vaccination. ${ }^{\text {" }}$ When plaintiffs refused, the commissioner ordered them quatantined in their house without judgment by a court, allegedly pursuant to local ordinance and state law. ${ }^{68}$

In proceedings ultimately reviewed by the Court of Appeals, plaintiffs alleged that they were imprisoned against their will and "they had been exposed to no contagion and were not afflicted with any disease, contagious or oherwise." Agreeing with them, the court held that when persons are to be quarantined, they must be "either"... infected with the contugious divedse, of ... exposed to it."70 There was no mandatory vaccination law and the court held that the commissioner could not simply declare that

"wherever any person shall refuse to be vaccinated, snch person shall be immediately quarantined and continued in quarantine until he consents to such vaccination." [To] give to [the commissioner] the right to compel the vaccination of every citizen ... if he would escape quarantine, seems ... unnecessary and ... an unwarrantable inference. ${ }^{71}$

Discharging the plaintiffs from the commissioner's custody, the court held "that an "isolation of all persons and things' is only permitted when they are 'infected with or exposed to' contagious and infectious diseases [which] means, when speaking of persons and things 'exposed' to disease, the actual fact and not a mere possibility,"?2.

A century later, during a tesurgence of tuberculosis in New Yok City, challenges to quarantine resurfaced. A tuberculosis patient contested an order continuing her detention in a hospital until she completed her conrse of medication or became more reliable in taking it. She "argue[d] that her multi-drug resistant tuberculosis [could] be treated, and the public health protected, by means less restrictive than detention in a hospital" for the projected 18 to 24 month period. ${ }^{73}$ In a succinct opinion, the Supreme Court, Appellate Division disagreed, holding that the New York City Health Department had shown by clear and convincing evidence that appellant was unable to comply voluntarily with her treatment in a less restrictive environment. In another case from the Supreme Court of Queens County a year later, a petitioner requested to be released from detention in a hospital for treatment of tuberculosis after failing three times 10 complete her treatment as an outpatient. The court held that the City Health Commissioner "demonstrated through clear and 
convincing evidence [petitioner's] inability to comply with a prescribed course of medication in a less restrictive environment," and upheld the commissioner's detention order. ${ }^{74}$

The appropriate standard of proof was considered explicitly in a case of irst impression following a consent order for involuntary hospital commitment for treatment of communicable tuberculosis. ${ }^{75}$ The Supreme Court of Suffolk County clarified that the burden of proof standard for a state actor is clear and convincing evidence "when the 'denial of personal or liberty rights' is at issue or when "particularly important personal interests are at stake." 76 The court applied the clear and convincing standard, which is intermediate between "the "fair preponderance of the evidence" standard [of] civil cases and the 'beyond a reasonable donbt' standard [of] criminal cases, [because the party bearing the burden of establishing a fact by clear and convincing evidence must satisfy the trier of fact that what he claims is actually so." 77 The court held that

[a]lhough there is no mention of [the appropriate] standard in [the] Public Health Law, this situation is analogous to situations where, because of mental infirmity, a person is sought to be detained in a mental facility against his will pursuant to Mental Hygiene Law. In such situations, where the petitioner is a govermmental agency, it must sustain its petition calling for involuntary detention of a person by clear and convincing evidence. Accordingly, this standard shall also govern here... ${ }^{78}$

The court's reliance on the Mental Hygiene Law standard reflects the federal case law standard for civil commitnent. 79

With regard to property, there are two ways in which government may deprive an owner of property. Property may be physically seized or its value may be diminished by regulation. Any such deprivation is compensable if it is a "taking" under the Fifth Amendment. In general, most physical seizures of property are considered compensable takings. Thus, seizures in a public health emergency of, e.g, a hospital or one of its operating rooms to treat victims, a drive-through restallrant for mass dispensing of antibiotics, or cell phone channels in order to maintain open lines for communication potentially would be compensable since they would be physical confiscations of private property by the government. However, the Supreme Court has held that emergency governmental seizures of property are not always takings, ${ }^{81}$ leaving open the question whether property seizures in a public health emergency would be deened compensable.

The Court considered regulatory takings in Lucas $y, S . C$. Codstal Council ${ }^{32}$ It reiterated the two categories of compensable takings (without regard to the legitimacy of any state interest) as either any "physical invasion" of ... property [for which] (at least with regard to permanent invasions), we have required compensation [or when] all economically beneficial or productive use of land" is denied. 83 The Licas Court held that in some instances a total regulatory taking that denies an owner all economically viable use of property might not be compensable but that a regulatory taking not under established nuisance or property law must be compensated. This analysis could pose problems during a novel public health emergency in that "it forces health officers to rely on often vague and outdated concepts of what constitutes a public health threat" ${ }^{n \& 4}$ and does not allow them to designate new nuisances if they wish to avoid compensation.

However, the Lucas dissent argued that when there is a sufficiently important state interest, total deprivations of property are not takings and are not compensable, citing Supreme Court prece- 
dents in which total property deprivations in situations of compelling state interest were not held to be compensable takings. ${ }^{86}$ Such a perspective adds uncertainty as to how courts might apply Lucas in a public health emergency and whether total regulatory deprivations in such a situation would be takings.

A public health emergency that is a bioterrorist event also conld be an act of war. In Vnited States v. Caltex (Philippines), Inc. ${ }^{37}$ the Court denied compensation claims for overseas oil terminal facilities that had been destroyed by the United States Army to prevent them from falling into enemy hands at the height of World War II. The Court first considered prior century wartime takings of equipment by the Amry for its own use, for which despite "[e]xtraordinary and unforeseen occasions [such as] in time of war or of immediate and impending public danger [nevertheless] the govermment is bound to make full compensation to the owner." The Court contrasted such situations with the matter at bar in which property was not "appropriated for subsequent use" to prevent its falling into enemy hands. Such destruction was not a compensable taking. ${ }^{90}$

In addition to compensation, the regulation and seizure of property are also subject to due process. Courts have held that substantive due process is not violated when legislatures regulate in areas of public healh concem. ${ }^{91}$ There are no definitive procedural due process requirements conceming property interests in public health emergencies, but the Supreme Court's consideration of procedural due process in the social welfare arena is instructive. Weighing the balance between the interests of an individual and the interests of government in challenges by recipients to terminations of their benefits, the Court upheld a requirement for a pre-temination hearing when welfare benefits were at stake ${ }^{52}$ but denied the right to a pre-termination hearing for disability benefits. ${ }^{92}$ The Elaridge Court explained the distinction between the due process required for termination from the two programs by reference to the public and private interests at stake and to "the risk of an erroneous deprivation of [the individual's] interest through the procedures used, and the probable value, if any, of additional or substitute procedural safeguards." The risk of hardship to the individual was less with the termination of disability benefits than with welfare benefits.

These holdings suggest that in a public health emergency, authorities should strive to comply with due process but that in some situations, courts will not always find that the interests of an individual sufficiently outweigh those of the government to require a hearing prior to depriving an individual of a property interest.

\section{The MODEL STATE EMERGENCY HEALTH POWERS ACT (MSEHPA)}

\section{A. THE MSLHPA}

Declaring after the tragedy of September 11, 2001, that public officials must have "the ability to prevent, detect, manage, and contain emergency health threats without unduly interfering with civil rights and liberties," 55 the Center for Law and the Public's Health at Georgetown and Johns Hopkins universities prepared the Model State Emergency Health Powers Act ("the MSEHPA")." The MSEHPA consists of eight articles dealing with planing for, detecting, tracking, and declaring a public health emergency; and with management of property, protection of persons, and providing public information during such an emergency. Almost all of the MSEHPA has been adapted from various state and federal statutory provisions.

The MSEHPA is intended to be a template for states to better prepare themselves through their laws to respond to public health emergencies such as bioterronist attacks and massive disease epidemics 
"and, at the same time, [to] protect individual rights and freedoms." 98 It is "an attempted best synthesis of advice, recommendations, and dialogue regarding the purpose of emergency public health law, its proper reach, and the protection of civil liberties and private property."

In New York, an edited version of the MSEHPA ("A.3207/S.185") has been introduced into the New York Legislature to enhance legal preparedness for bioterrorism. It consists of additions to Section 29 of the Executive Law (adding measures for plaming for, and declaring a public health emergency) and a new Article 10 of the Public Healh Law (adding measures for management of property, protection of persons, and providing public information during a public health emergency) ${ }^{100}$ A hearing on the predecessor bills to A.3207/S.185 was held though the bills were not adopted into law. ${ }^{101}$

Of note, the MSEHPA defines a public health emergency as being caused by bioterrotism or by a naturally occurring event. ${ }^{102}$ In contrast, A.3207/S.185 identifies only bioterrorism as the cause of a public health emergency, narrowing its scope and utility since its provisions would not be applicable in the event of a naturally occurning biological disaster. ${ }^{10 \%}$ Another significant modification from the MSEHPA in A.3207/S.185 is the exclusion of the MSEHPA provisions for detecting and tracking public health emergencies. This is perhaps because detection and tracking provisions would be applicable to a variety of public health purposes, and it would not make sense to propose such innovations only for bioterrorism survellance. However, exclusion of the provisions potentially limits opportunities to enhance the state's surveillance and monitoring capacities. The legislative record is silent as to the motivations for these and other variances from the text of the MSEHPA.

\section{B. REACTONS TO THE MSEHPA AND ITS NEW YORK VERSTON}

The MSEHPA is controversial for several reasons. ${ }^{104}$ The very appropriateness of enhancing state power to respond to bioterrorism rather than strengthening federal response capabilities has been questioned in light of the anthrax attacks of $2001 .^{105}$ Given that bioterrorist acts and their effects can cross state borders rapidly and that in addition to being public health events, bioterrorist acts also are crimes or even acts of war, George Annas, a major critic of the MSEHPA, calls bioterrorism "an inherently federal matter." 105 Another critic has argued for "state regionalization" as the "optimal plan for the United States ... for the initial response to a bioterrorist attack" 107 given the "speed with which disease spreads in the twenty-first century, coupled with gaping differences between funding, staffing, and resource levels of state and local public health departments" ${ }^{9108}$ and the need for "some level of uniformity" 110 of response.

The MSEHPA also appears to favor comprehensive public health interventions too heavily at the expense of civil liberties, ${ }^{110}$ despite the belief of one of its authors that the MSEHPA maintains "the delicate balance between public health and civil liberties in a constitutional democracy."11" One commentator asserts that the MSEHPA "provides a strong basis ... to reconsider [state] public health laws and update them as necessary but that [it] must be altered so as to bolster privacy and civil liberty protections that are unjustifiably weakened to an unecessary degree."1.12

Annas has leveled other criticisms against the MSEHPA. These include the arguments that it is difficult to assess the value of the MSEHPA because it is proposed as a remedy to an unspecified prob$1 \mathrm{em}$, it is inappropriate to give public health authorities primacy in response to bioterorism, given the equally important role to be played by physicians and hospitals; ${ }^{114}$ it is unreasonable and 
unnecessary to compel participation by the medical community and the public in response to bioterrorism when the September 11, 2001, experience demonstrated their willingness to cooperate voluntarily $^{115}$ as did the 2003 SARS outbreak experience in Toronto, ${ }^{115}$ if public healh anthorities compel cooperation, it "would ...engender distrust [and perhaps active non-cooperation], because it would suggest that [they] could not provide valid reasons for their actions," 117 a large-scale involuntary quarantine is logistically impossible in today's world of the Internet, "televised news 24 hours a day, cell phones, and automobiles" (and in fact there has been no large scale quarantine in the United States for more than 80 years);, ${ }^{118}$ and state governors already have sufficient emergency powers, ${ }^{1 i g}$ although Annas also agrees that "many state public health laws are outdated and perhaps inadequate....".12\%

Daniel Reich, another critic of the MSEHPA, has pointed out that the definitions of "quarantine" and "isolation" in the MSEHPA may be overly broad and inconsistent with standard definitions of the tems." Generally, quarantine is when individuals who have been or are reasonably likely to have been exposed to a communicable infection are restricted in their movement to a specified location, often the home, to allow time to see if they develop disease. ${ }^{122}$ Isolation refers to the separation of a known or reasonably likely to be infected individual from others to prevent further transmission. $^{1.23}$ However, A.3207/S.185 defines quarantine as

the physical separation and confinement of an individual of groups of individuals, who are or may have been exposed to a contagious or possibily contagiotis disease and who do not show signs or symptoms of a contagions disease, from non-quarantined individuals, to prevent or limit the transmission of the disease to non-quarantined individuals. 124

It defines isolation as "the physical separation and confinement of an individual or groups of individuals who are infected or reasonably believed to be infected with a contagious or possibiy contagrows disease from non-isolated individuals, to prevent or limit the transmission of the disease to non-isolated individuals." 125

The inclusion of individuals who "may have been exposed" to a contagions disease without specification of a standard for the required degree of exposure potentially allows too broad of a group to be swept up. ${ }^{12 \epsilon}$ It conflicts with the New York Court of Appeals in fe Smith holding that when persons are to be quarantined, they must be "either ... infected with the contagious disease, or ... exposed to it." Permitting quarantine after exposure to, and isolation for infection with, a "possibly contagious disease" permits decisions to be made arbitrarily and in the absence of a "scientific basis for this determination." 128 Since A.3207/S.185 does not specify a standard for detemining the likelihood of contagiousness of a disease, it gives considerable leeway to the discretion of the public health authority by allowing for quarantine and isolation based on popular professional suppositions that appear reasonable but have no scientific basis.

Amnas finds many deficiencies in the article of the MSEHPA having to do with "protection of persons.".12\% A.3207/S.185 permits the public health authority to isolate or quarantine "any person whose refusal of medical examination or testing results in uncertainty regarding whether such person has been exposed to or is infected with a contagious or possibly contagious disease, or otherwise poses a danger to public health."130 Annas cautions that this is the equivalent of no standard at all since a refusal will result almost alwas in uncertainty, and the section thus allows too broad 
a discretion to isolate and quarantine. ${ }^{131}$ A.3207/S.185 also permits the health authority to isolate or quarantine any person who has "not been vaccinated, treated, tested or examined," allowing too broad a power, since such persons could include, among others, those who have not yet been processed merely because of public health staffing shortages.

A.3207/S.185 allows for compulsory vaccination without exception, ${ }^{133}$ as the MSEHPA has, for a vaccine "reasonably likely to result in serious harm to the affected individual,"134 whereas an exception is allowed in both A.3207/S.185 and the MSEHPA for treatment "reasonably likely to result in serious ham to the affected individual." ${ }^{35}$ Those individuals refusing vaccination or treatment "for reasons of health, religion, or conscience" may be quarantined or isolated. ${ }^{136}$ Annas is critical of the latter provision, observing that "[t]oday, all adults have the constitutional right to refuse examination and treatment, and such a refusal should not result in involuntary confinement simply on the whim of a public health official." ${ }^{\text {i37 }}$ The right to refuse treatment has been articulated by both the Supreme Court and the New York Court of Appeals. ${ }^{13}$

A.3207/S.185 allows the health authority up to ten days to obtain a court order to continue isolation or quarantine that has been imposed upon individuals or groups of people, ${ }^{139}$ and allows the court up to five days to hold a hearing, with a ten-day continuance allowed "in extraordinary circumstances and for good cause shown." or groups of people are afforded an opportunity to be heard. Hearings need not be individual; under certain circumstances the court may consolidate individual claims into a group. ${ }^{i 41}$ A group hearing, though perhaps expedient in an emergency, nevertheless is worrisome from a civil liberties perspective.

Annas notes that "the standard for a continued quarantine appears to be the finding that the person would 'significantly jeopardize the public health authority's ability to prevent or limit the transmission of a contagious or possibly contagious disease to others," "itz which wrongly shifts what should be an emphasis on an individual's status and its risk to the public's health to the prerogatives of government bureaucracy. ${ }^{143}$ of note, A.3207/S.185 states that the standard of proof for granting a health authority's petition for isolation or quarantine is a preponderance of the evidence, ${ }^{144}$ which is counter to New York precedent that the standard is one of clear and convincing evidence. ${ }^{145}$

A.3207/S.185 has provisions regarding participation of medical and emergency health care providers within the state that Amas finds "especially tronblesome." 146 During a public health emergency due to bioterrorism, health personnel may be required "to assist" the public health authority "as a condition of continued licensure [or as a condition of] the ability to continue to function as a health care provider in this state, ${ }^{, 147}$ introducing an element of coercion that could work at cross-purposes to fostering an effective response capacity. Also as a condition of licensure or functioning in the state, health care facilities may be required to provide services or the use of facilities "includ[ing] transferring the management and supervision of the health care facility to the public health authority for a limited or unlimited period of time,"148

A.3207/S. 185 has compensation provisions for lawful takings of private property for temporary or permanent use by public health officials during a declared bioterrorism emergency, ${ }^{149}$ thongh not for destruction of property reasonably believed to endanger public health. ${ }^{150}$ To destroy property, public health officials must institute civil proceedings "to the extent practicable."151 
A.3207/S. 185 offers health personnel immunity from civil liability, even in the case of death, personal injury or property damage, except for gross negligence or willful misconduct. ${ }^{152}$ Interestingly this appears to be a greater degree of legal exposure than provided for in the Defense Emergency Act, which confers total immunity from liability. ${ }^{153}$ A.3207/\$.185 also extends the same degree of immunity from civil liability to the Governor, the public health authority, participating state and local officials, ${ }^{154}$ and "any private person, firm or corporation, and the[ir] employees and agents" either under contract with, ${ }^{155}$ of "who renders assistance or advice" at the request of the government. ${ }^{156}$ Out-of-state emergency health care providers are granted greater immunity, being held liable only for "reckless disregard for ... life or health." is?

The degree of immunity for so broad a spectrum of state actors in the face of arguably vague standards for the protection of persons appears to be a final, if not fatal, flaw in A.3207/S.185, by tipping the balance to favor sweeping, far-reaching public health interventions at the expense of civil liberties. The critical defect is inadequate accountability. "Citizens should never be treated against their will by their government, but if they ever are, they should be fully compensated for injuries suffered as a result." 158

\section{The Law In New York And The Promosed Law: An Assessment}

Although in disparate parts, New York's legal capability to respond to a public health emergency is robust. The New York State Defense Emergency Act enables the State Civil Defense Commission to plan and promulgate regulations regarding most conceivable aspects of a response to an actual or imminent attack. ${ }^{159}$ In addition to state-level authority, localities may consolidate their own civil defense efforts and may form nutual aid agreements. ${ }^{160}$

In the event of an attack, defined broadly, the State Civil Defense Commission has the power to take any state assets and any and all real or personal property. ${ }^{i 61}$ The commission also has the power during an attack to appropriate civil defense powers from connties and cities, and may have the power to give counties and cities far-reaching authority to compel evacuation, take or destroy property, and draft people into service. ${ }^{152}$

The govemor may designate any part of the state as an emergency health and sanitation area, which confers authority on the local board of health to take and enforce necessary measures to protect public health. ${ }^{153}$ State actors, including designated private individuals and entities, enjoy absolute immunity for good faith civil defense-related actions even if they result in death or property damage. ${ }^{164}$

Both the State and Local Natural and Man-Made Disaster Preparedness legislation and the Defense Emergency Act enable a state disaster preparedness planning capacity though the legislation gives additional detail not in the Act. The legislation also includes explicit authority after the declaration of a state of emergency for the imposition of a qualified form of martial law by the governor or a local chief executive. ${ }^{165}$

The Public Health Law, through its nuisance and communicable disease provisions and the State Sanitary Code, gives state and local public health authorities powers of surveillance and control of nuisances and of persons and things infected or exposed to a long list of communicable diseases, induding broad powexs of quarantine and isolation with notice and hearing. ${ }^{156}$ However, there are no provisions to mandate vaccination or treatment other than for students. Public health anthorities may seize or destroy articles hazardous to the public health and may regulate public health nuisances. ${ }^{16}$ All persons have a duty to report known or suspected cases of communicable disease to public heal th authorities. ${ }^{168}$ 
Federal case law upholds the reasonable use of state police power to protect public health and safety. ${ }^{169}$ New York precedents have clarified the Public Health Law by upholding mandatory vaccination of school children to promote the public good, ${ }^{170}$ proscribing vaccination in the clear absence of infection or exposure to contagious disease, ${ }^{17 \mathrm{i}}$ setting a standard of proof of the need for quarantine of clear and convincing evidence, ${ }^{172}$ and mandating the least restrictive quarantine environment. ${ }^{173}$

The Constitution requires compensation for physical or regulatory takings, though for the latter only if all value is lost and the taking is not under established nuisance or property law. ${ }^{174}$ In a public health emergency or wartime, certain physical takings may not be compensable. ${ }^{175}$ Substantive due process is not violated by regulations that bear some rational relationship to a legitimate legislative purpose in a public health emergency. ${ }^{176}$ The requirements of due process in a public health emergency might be determined by a balancing of private and public interests and the risk of hardship to an individual with the "value ... of additional or substitute procedural safegnards."177

A.3207/S.185, introduced this year in the New York Legislature, contains a number of provisions that ate non-controversial and that could add meaningful elements to New York law. ${ }^{178}$ However, A.3207/S.185 also has controversial aspects, raising cautionary signals about enactment. First, it is unclear whether it is appropriate to strengthen state rather than federal power given the potential for widespread diffusion and the criminal nature of bioterrorism. As well, the extent to which A.3207/S.185 tips the balance away from civil liberties and toward public health control of persons and property should be clarified, made explicit and discussed as a matter of public policy before any law is passed. Even the premise in A.3207/S.185 that a mass quarantine could be imposed effectively in today's world of instant electronic communications is uncertain. By the time a state bureancracy has mobilized itself, significant numbers of people will have heard of impending plans in an e-mail or a cell phone call and fled. Part of the problem with A.3207/S.185 is that conceptualizations of possible bioterrorist events are so varied that a "one size fits all" stand-alone statute may be meaningless.

Among the controversial provisions of A.3207/S.185 are the degree to which it gives primary responsibility for responding to bioterrorism to public health authorities rather than equally including physicians and hospitals; the compelling of health care professionals and facilities to assist in the event of bioterrorism even if compensated; the broad discretion granted to public health officials to decide who and when to exam, vaccinate, treat, quarantine, and isolate; the perception of inadequacy in the due process afforded those contesting quarantine or isolation; ${ }^{170}$ and its immunity provisions.

\section{Next Steps}

Ultimately, the primary benefit of the MSEHPA may be "the extent [to which] it encourages states to review their emergency laws." 180 It may be worthwhile also to review New York Public Health Law to improve it rather than adopting A.3207/S.185 in its entirety. One valuable source for such a review is the Turning Point Model State Public Health Act," the goal of which is "to assist state and local governments to assess their existing public health laws and update laws to effectively address a range of modem public health issues." ${ }^{32}$ The Tuming Point Model State Public Health Act includes inter alia a section and other relevant provisions on public health mergencies derived from the MSEHPA ${ }^{1.82}$ and explicit provisions that address criticisms of the MSEHPA. ${ }^{184}$ 
Philosophic and ethical issues raised by A.3207/S.185 and the MSEHPA ${ }^{185}$ should be considered and resolved explicitly in the Legislature before enactment of any of its provisions. Provisions of A.3207/S.185, the MSEHPA, and from other sources merit selective incorporation into New York law, allowing meritorious and relevant passages to be included while avoiding controversy and redundancy. Any adopted provisions should be appropriately amended for consistency. For example, A.3207/S.185 does not include a role for local governments in public health emergency response. Local involvement is an important component of public health practice in New York, a reality that is reflected in statutory language. As well, inconsistencies in the proposed law with prevailing standards of liability, immunity and proof should be resolved.

The sections on detection and tracking of the MSEHPA should be considered for enactment in New York. Surveillance is a bedrock public health function. Prior to, and during, potential contemporary public health emergencies "public health officers may need additional authorities beyond [conventional] surveillance and disease reporting." 136 "Given the explosion of methods for information-gathering and of types of information available since surveillance laws were last enacted, the enhancement of state and local detection and tracking capabilities would be an invaluable addition to public health.

With regard to measures for the control or protection of persons, standards for decision-making in the Public Health Law should be made more explicit and reflect civil libertarian values that were not considered when the laws were initially drafted. Non-disease-specific provisions for examination, vaccination and treatment should be incorporated. Their development should be informed by a recognition of the tension between (a) the need for public health officials to compel certain outcomes in order to optimize the response to a rapidly evolving, mass public health emergency and (b) the potential for mandates to foment reactions that range from public mistrust of authorities to overt civil disobedience. Provisions for the control of property in New York law should be updated to reflect principles of compensation and due process. 


\section{ENDNOTES}

1 U.S. CONST. amend. $\mathrm{v}$.

2 U.S. Const, amend. XIV, $\$ 1$.

3 N.Y. CONST art. I, \& 6.

4 N.Y. CONST, art. I, \& 7(a).

5 Lawrence O. Gostin, Model State Emergency Health Fowers Act, December 21, 200I (MSEHPA), ath http/fwww publichealthlaw netMSEHPAMSEHFA2, pdf (last visited Mar, 25, 2005).

6 See 42 U.S.C. 8264 (2005).

7 N.Y. PUB. HELUTH LAW art. 13 (Consol. 2004).

8 id. art. 21

N.Y. CONP. CONES R. \& REGS. tit. 10, ch. I (2005).

10 New York State Defense Emergency Act, N.Y. UNCONSOL. LAW ch. 131 (Consol. 2004).

11 N.Y. Corap. CODEs R. \& Recss. tit. 9, \$ 5.132 (2005) (Designating the State Prevention and Preparedness Council; Establishing the Positions of Senior Advisor to the Governor for Counter-Terrorism and Senior Advisor to the Governor for Disaster Preparedness and Responze; and Revoking Certain Executive Orders.).

12 N.Y. EXEC. LAW art. 2-B (Consol. 2004). The legislation does not have a formal title.

13 N.Y. PUB. HEALYY LAW \& $1300(1)$ (Consol. 2004).

14 Id. $8206(9)$.

$15 \mathrm{ld} .1303(3)$.

$16 \%$. $2100(1)$ (Consol. 2004).

17 ld. $\$ 2100(2)(a)$.

18 Id. $\$ \$ 2164$ (against polio, mumps, measles, diphtheria, German measles, chickenpox, Haemophilus influenzae type b, whooping cough, tetanus, and hepatitis B), 2165 (against measles, mumps and German measles), 2176 (against meningococcal meningitis).

19 N.Y. COMP. CODES R. \& RESS. tit. $10, \$ 2.12(2005)$.

20. N.Y. PUD. HEALTH LAW $\$ 2120(1)$ (Consol. 2004).

21 id. $\$ 2120(2)$.

22 Id. $\$ 2120(3)$.

23 N.Y. COMP. CODES R. \& RESS. tit. $10,81.11(2005)$.

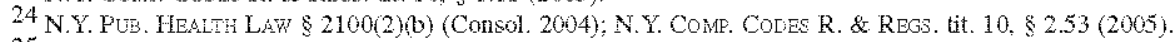

25 N.Y. CONP. CODES R. \& RESS. tit. $10,82.1$ (a) (2005).

$26 s e$, e.g. N.Y. PUR. HEALTH LAW $\$ 82130-39$ (HIV), 2140-46 (rabies), 2220-30 (uberculosis), $2300-11$ (STDs), $2780-87$ (HIV) (Consol. 2005).

27 New York State Defense Emergency Act, N.Y. UNCONSOL. LAW ch. 131 \& (Consol. 2004).

$28 \bar{T}$. .82.

$291 d \$ 2-\mathrm{a}$.

30 Id. $\$ 20$.

31 These include provisions for "[m]edical treatment, food, clothing and shelter[,] materials and facilities[;] training and information [for] the public [and] municipal agencies[; e]vacuation of certain persons in the event of or anticipation of attack, including the establishment of temporary housing and schools and other emergency facilities[; clontinuity of [g]overnment[; p]ublic order[, including the c]ontrol of pedestrian and vehicular traffic, transportation and communication facilities, public utilities and the conduct of persons other than members of the armed services or military forces in the event of an attack, during drills and tests and immediately prior and subsequent thereto." $t a z$. 821 (Consol. 2004).

32 Id. $\$ 3(2)$.

33 The commission has authority to "(a) assume direct onerational control of any or all civil defense forces; (b) order, direct, requite and use the personnel, materials, facilities and services of any agency, public oflicer, or political subdivision of the state, ... (d) take, use or destroy any and all real or personal property, or any interest therein, necessary or proper for the purposes of civil defense; (e) execute any or all of the civil defense powers and duties of any county or city after notifying the chief executive officer of such county or city if such notification is possible." New York State Defense Emergency Act, N.Y. UNCONSOL. LAW ch. 131 \& 25(1) (Consol. 2004).

34 Id. $\$ 25(2)$. The Act states that the permitting of counties and cities to execute the aforementioned powers is subject not only to the "plans, regulations and orders" of the commission, but also to a "State Defense Council" created by the Act. $I d . \$ 25(2)$. The existence of the State Defense Council is terminated by the Act at the termination of the then national emergency. $I d \& 3(13)$. This likely was in the early $1950 \mathrm{~s}$. If the permitting of expanded powers 
to counties and cities during an attack requires action by both the Civil Delense Commission and a State Defense Council that no longer exists, it is uncertain whether the Commission alone could confer such permission. Thus, it is unclear if the Act's authorization of the delegation of control over the movements of persons and property to counties and cities remains lawful.

35 Id. \& 27 .

36 Td. \& 28.

37 Id. 43 .

38 tid.

39 "The state, any political subdivision, municipal or volunteer agency, ... or any individual, partnership, corporation, assuciation, ... in good faith carrying out, complying with or attempting to comply with any law, any rule, regulation or order duly promulgated or issued pursuant to this act ... in preparation for anticipated attack, during attack, or following attack or false warning thereof, or in connection with an authorized drill or test, shall aot be liable for any injury or death to persons or damage to property as the result thereof: New York State Defense Emergency Act, N.Y. UNCONSOL. LAW ch. 131 \& 113 (Consol. 2004).

40 N.Y. EXEC. L.A.W art. 2 B (Consol. 2004). As justification, the Legislature asserted "that it muzt provide for preparations to prevent, meet, delend against and recover from, dangers and problems arising from ... a wide variety of disasters, often caused or compounded by mankind's own acts ... with the least possible interference with the existing division of the powers of the government" 1978 N.Y. Laws ch. 640, \& 1 (cited at N.Y. EXEC. LAW \& 20 (Consol. 2004)).

411978 N.Y. Laws ch. 640, \& 1 (cited at N.Y. EXEC. LA. \& 20 (Consol. 2004)).

42 N.Y. EXEC. LAW $\$ 20(1)$ (a) (Consol. 2004)

43 Id. $\& 20(1)(\mathrm{b})$.

44 fid. $820(1)(\mathrm{c})$.

$45 \bar{t} d . \S 21(1)$

46 id. $\$ 21(2)$

47 di. $\$ 21(3)(\mathrm{c})$.

48 N.Y. EXEC. LAW \& 21 (3)(j) (Consol. 2004). Powers of the civil defense commission are enumerated in the Defense Emergency Act, N.Y. UNCoNsol. LA.Y eh. 131 (Consol. 2004).

49 N.Y. EXEC. LAW \& 22 (3) (Consol. 2004).

50 Ia. $\$ 23(1)$.

51 fd. $81(3)(\mathrm{e})$.

52 tid. $\$ 2 l(3)(\mathrm{f})$.

53 (d. $21(3)(\mathrm{f})$.

54 Id. $\$ 28(1)$.

55 The chief executive "may promulgate local emergency orders to protect life and property or to bing the emergency situation under control. .. Such orders may ... provide for ... the establishment of a curfew and the prohibition and control of pedestrian and vehicular traffic;... the designation of specilic zones within which the occupancy and use of buildings and the ingress and egress of vehicles and persons may be probibited or regulated; ...the regulation and closing of places of amusement and assembly; ...the suspension or limitation of the sale, dispensing, use or transportation of älcoholic beverages, firearms, explosives, and flammable materials and liquids; ...the prohibition and control of the presence of persons on public streets and places; ... the suspension within any part or all of its teritorial limits of any of its local laws, ordinances or regulations, or parts thereof subject to federal and state constitutional, statutory and regulatory limitations [and also] subject to ... standards and limits [as described in the legislation]." N. Y. Exec. LAw \& 24(1) (Consol. 2004).

56 10. $828(4)$.

57 Id. \& $29-\bar{a}$.

58 Note that litigation has been limited to the Public Heath Law and its antecedents. There are no civil liberties cases under the Defense Emergency Act or the State and Local Natural and Man Made Disaster Preparedness legislation.

59 Jacobson v. Massachisetts, 197 U.S. 11 (1905).

60) $7 d$. at 26 .

$61 \mathrm{id}$.

62 Viereigter w. White, 72 N.E. 97 (N.Y. 1904).

63 .

$64 \mathrm{fd}$.

65 In re Snith 40 N.E. 497 (N.Y. I895).

$66 \bar{t} d$.

$67 \mathrm{id}$. 
$681 d$, at 498 .

$69 \mathrm{Id}$.

70 id

7140 N.E. at 498.

72 Id at $498-99$.

73 City of New Yort v. Doe, 614 N.Y.S.2d 8, 9 (App. Div. 1994).

74 City of New York 1. Antrinstse R., 630 N.Y.S.2d 1008, 1011 (Sup. Ct. Queens County 1995 ).

75 Bradley v. Crowell, 694 N.Y.S.2d 617 (Sup. Ct. Suffolk County 1999).

76 Id. at 618 (citation omitted).

77 Id.

78 Id. (citation onitted).

${ }^{79} \mathrm{Sec}$ Addrington $v$. Teras, $441 \mathrm{USS}, 418$ (1979) (holding in a challenge to a state civil commitme nt proceeding that the standard of proof was clear and convincing evidence).

80 James J. Mistahi et al., Legul Authorities for Interientions During Public Health Energencies, in LAW IN PUBLIC HealTh Practlee 195, 203 (Richard A. Goodman et al. eds., 2002).

81 See, e.g., Miller v. Schoere, 276 U.S. 272 (1928) (holding in a suit challenging a Virginia statute requiring certain trees to be cut when trees of much greater economic value were threatened by infection that the exercise of police power is characterized by the state's choosing to favor the public interest over a private property interest and that no compensation need be paid (plaintiff was left with the salvage value of the cut wool)

82 Lutas v. S. C. Coastal Courcil, 505 U.S. 1003 (1992).

$83 \mathrm{Id}$. at 1015 (holding in a challenge to a regulation prohibiting construction of habitable structures on beachfont property that there was a compensable taking unless the regulated use was prohibited under " principles of nuisance. and property law," $i d$, at 1031 , and remanding).

84 Mistahi, sipra note 80 , at 203 .

85 "This Court repeatedly has recognized the ability of government ... to prohibit uses of property injurious to public health, safety, or welfare without paying compensation." Lacas i. S.C. Coustal Councib, 505 U.S. 1003, 1047 (1992) (Blackmun, J., dissenting).

86 "TIn Keystone Bituminous Coal, the Court summarized over 100 years of precedent: "The Court has repeatedly upheld regulations that destroy or adversely affect real property interests." Id. at 1049 (quoting $K$ eystone Bituminous Coul Ass'n v. DeBereulictis, 480 U.S. 470, 489, n.18 (1987)).

87 United States v. Caltex (Philippines), Ino, 344 U.S. 149 (1952).

88 1d. at 152, n.2.

89 id. at 155 .

${ }^{90}$ See also United Stutes 1. Central Euroka Minivg Co, 357 U.S. 155 (1958) (denying compensation for mandated wartime conservation of mining resources and holding that the Court has "treated the issue as to whether a particular governmental restriction amounted to a constitutional taking as being a question properly tuming upon the particular circumstances of each case[.] In the context of war, we have been reluctant to find that ... regulation [depriving an owner of the most profitable use of property] requires compensation to be paid for resulting losses of income[. The effect of such regulation is] insignificant when compared to the widespread uncompensated loss of life and freedom of action which war traditionally demands." $T z$. at 168 ).

91 See, e.g, Beatrie v. City of New York, $123 \mathrm{~F} .3 \mathrm{~d} 707 \mathrm{2d} \mathrm{Cir} .1997$ ) (holding in an unsuccessful challe nge to a New York City regulation prohibiting indoor smoking that a "rational relationship between the legislation and a legitimate legislative purpose," id at 711 , was sufficient for substantive due process and that the burden of disproving such a relationship was on the challenger); New York City Friends of Ferrets v City of New York. 879 F. Supp. 529 (S.D. N.Y. 1995) (holding in an unsuccessful challenge to New York City regulation of ferrets that "deprivation of private property pursuant to an exercise of police power is constitutionally permissible where the challenged legislative enactment bears a rational relationship to legitimate legislative goal or purpose." id. at 534).

92 Goldbergy $x \in$ Kily, 397 U.S. 254 (1970).

93 Matheris' v. Eldratge, 424 U.S. 319 (1976).

94424 U.S. at 335.

95 Gostin, sigra note $58103(\mathrm{~g})$.

96 Gostin, sipra note 5 .

97 New York law is minimally used as a source. The MSEHPA "definition for 'organized militia" was adapted from NY CLS MiLITARY \$ 1 (2001)," Gostin, wpra note 5, at 12, "[s]ection 302, the main text under "Tracking' was adapted from ... N.Y. COMP. CONES R. \& RECs. tit. 10, 82.6 (LEXIS through 0et. 12,2001 ), id. at 17, and "Is]ection 602 [Medical examination and testing] was adapted from ... N.Y. COMP. CODEs R. \& REGS. tit. 10, \& 2.5 
(LEXIS through Oct. 12, 2001)," id. at 26.

98 Lawrence O. Gostin et al., The Model State Emerzeno Health Powers Act: Planning for and Response to

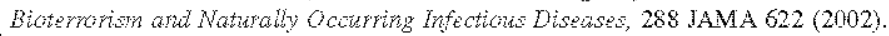

99 fld at 625 .

100 The legislation has been introduced in three of the last four legislative sessions, most recently as A.3207, 20042005 Assem., Reg. Sess. (N.Y. 2005)/S.185, $2004-2005$ S., Reg. Sess. (N.Y. 2005) (hereinatter A.3207/S.185).

101 Fublic Health Emergency Flanxing and Response and the Hode! Enstrency State Health Fowers Act: Hearing on A.9508 A. Before the Assern. Comzins on Healih, Codes, Gov't Operations, 20012002 Assem., Reg. Sess. (N.Y. 2002).

102 A natural event occurs with the appearance of a novel or previously controlled or eradicated infectious agent or biological tuxin." Gostin, sigpra note $5, \& 104(\mathrm{~m})(1)(\mathrm{ii})$.

103 A.3207/S.185, N.Y. PUB. HEALTH L.W $\$ 1003(13)$ (proposed). The legislation consists of four sections. The first section is a statement of legislative intent. The second section is the proposed additions to 829 of the Executive Law. The third section is the proposed article 10 of the Public Health Law. The fourth section is the stated effective date. References to A.3207/S.185 cite to the proposed sections of the Executive Law and the Public Health Law within sections two and three, rather than to the four sections of the legislation itself.

104 I will consider only those sections of the MSEHPA that are included in A.3207/S.185, as those are the ones potentially applicable in New York. Also, as a comention, I will refer to 'the MSEHPA' when considering commentary made exclusively with respect to the MSEHPA (even though it applies to A.3207/S.185) and to 'A.3207/S.185' when discussing A $3207 / \mathrm{S} .185$.

105 George J. Annas, Biotermptism, Public Health, and Civil Liberies, 346 NEw ENG. J. MEL. 1337 (2002).

$106 \mathrm{Td}$

107 Matthew E. Brown, Reconsitering the Hodel State Emergency Heaith Powers Act: Toward State Regionalizaturn in Bioterrorisy Response, 14 ANN. HEdLA L. 95, 97 (2005).

108 Tiz at $100-01$.

109 Id. at 120 .

110. Annas, supra note 105 , at 1341 .

111 Gostin, sippra note 98 , at 623 .

112 Daniel S. Reich, Modemizing Local Responses to Public Heath Emergencies: Bioterrorism, Fplidemics, and ihe

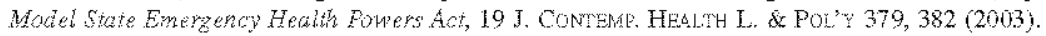

113 Annas, urpra note 105, at 1338 .

114 Id. at 1339 .

$115 \frac{1}{2}$.

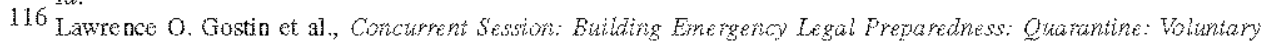
(\% Not?, 32 J.L. MED. \& ETHICS 83 (2004).

117 Annass, supra note 105 , at 1340.

$118 \mathrm{~g} d$.

$119 \frac{1}{1 d}$.

120 i. at $1337-38$.

121 Reich, sypra note 112 , at $408-10$.

122 See Dorland's Illustrated Medical Dictionary (26 th ed. 1985 ).

$123 \mathrm{Id}$.

124 A.3207/S.185 \& 1003 (15) (emphasis added).

125 Id. $81003(8)$ (emphasis added).

126 See Reich, sipra note 112 , at $408-410$

127 In re Symith, 40 N.E. 497, 498 (N.Y. 7895$)$.

128 Reich, sapra note 112 , at $408-410$.

129 A.3207/S.185 \$\$ 102027.

130 Tz. \& $1021(3)$.

131 Annas, sitpra note 105 , at 1341.

132 A.3207/S.185\& $1023(1)$.

$133 \mathrm{Id} .81022(1)$ (perhaps this is an error in transeription).

134 Gostin, supra note $5,8603(a)(2)$.

135 A.3207/S.185\&1022(2)(b).

136 Ii. $\$ \$ 1022(1)(\mathrm{b}),(2)(\mathrm{c})$.

137 Annas, simpra note 105, at 1340.

138 See, e.g., Cruzar v. Director, Miswont Dep't of Heath, 497 U.S. 261 (1900) (holding in a challenge to an order to 
withdraw artificial nutrition devices that patients generally have the right to refuse treatment); Rivers is Katz, 405 N.E.2d 337 (N.Y. 1986 ) (holding in a challenge by institutionalized patients to the involuntary administration of antipsychotic medication "that every individual "of adult ye ars and sound mind has a right to determine what shall be done with his ow a body' and to control the course of his medical treatment," id. at 341 (citation omitted).

139 A.3207/S.185\& $1024(1)(d)$.

$140 \mathrm{Id}$. $81024(2)(\mathrm{d})$.

141 i. $\$ 1024(5)(\mathrm{b})$.

142 Annas, supra note 105 , at 1341 (quoting Gostin, supro note $5,8605(a)(1)$ (also found at A.3207/S.185 8 $1024(1)(a))$ ).

143 The standard seems to be the degree to which release from quarantine hampers the ongoing emergency work of the public health authority, instead of the determination that an individual or a group is not infected and consequently no longer an actual or a potential risk to the public's health. One can conceve of a situation in which large numbers of people are continued in quarantine for convenience' sake merely to avoid adding to massive chaus that has arisen during a bioterror event, rather than justifying the continued quarantine with a "true" public health reason.

144 A.3207/S.185 \& $1024(2)(\mathrm{e})$.

145 Braulley \%. Crowel, 694 N.Y.S.2d 617 (Sup. Ct. 1999).

146 Annas, sippra note 105 , at 1341 .

147 A.3207/S.185\&1027(1).

1.48 Id $\$ 1011(2)$.

149 . 3 . $1044(1)$

150 "Just compensation. [shall be paid] to the owner of any facility or materia] that is law fully taken or appropriated by the public health authority for its temporary or permanent use [though pay ment] shall not be provided for facilities or materials that are closed, evacuated, decontaminated or destroyed when there is reasonable cause to believe that they may endanger the public health..." $1 d . \& 1015$. A.3207/S.185 also has a provision for determining the amount of any compensation. $I d . \S 1044(3)$.

$151 \mathrm{Id}$. 1016 .

152 Id. $\$ 1043(2)(\mathrm{c})$. The legislation is silent as to any criminal liability.

153 N.Y. UnCONJOL. LAW ch. 131 \& 113 (Consol. 2004).

154 A.3207/S.185 \& $1043(1)$.

155 ic. $\$ 1043(2)(b)$.

156 Id. $\$ 1043(2)(\mathrm{c})$.

157 Iu. $\$ 1027(2)(\mathrm{c})$.

158 Annas, sippra note 105 , at 1341.

159 New York State Defense Emergency Act, N.Y. UNCONBot. LÁW ch. 131 \$ 21 (Consol. 2004).

$1600^{\prime}$ Id $8 \$ 27-28$

$161 \mathrm{Id}, 8 \mathrm{~s} 3,25$

$162 \mathrm{Td} .825$.

163 i.l. $\$ 43$.

$164 \mathrm{Id} \& 113$

165 N.Y. EXEC. LAW $\$ \$ 24(1), 29(\mathrm{a})$ (Consol. 2004)

166 N.Y. PUB. HEALT L4W $\$ \$ 1303(3), 2100(1)$ (2)(a), 2120(1) (3) (Consol. 2004).

$167 \mathrm{Id}$. $\$ 2100(2)$ (b) (Consol. 2004), N.Y. COMF. CODES R. \& REGS. tit. 10, \& 2.53 (2005)

168 N.Y. COMR. CONES R. \& REgs tit. 10 , \& $2.12(2005)$.

169 Jacubson 19 Massachuseits, 197 U.S. 11 (1905).

170 Vierneister o. White, 72 N.E. 97 (N.Y. 1904).

171 in re Sintith, 40 N.E. 497 (N.Y. IS95)

172 Bradloy of Crowelh, 694 N.Y.S.2d 617 (Sup. Ct. Suffolk County 1999).

173 City of New Yor lo Doe, 614 N.Y.S.2d 8 (App. Div. 1994); City of New York V. Antainette R., 630 N.Y.S.2d 1008 (Sup. Ct. Queens County 1995).

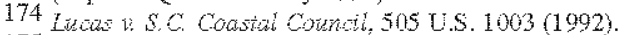

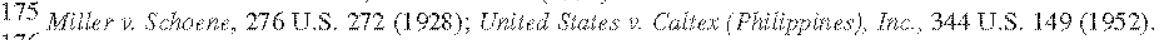

176 Beattie $v$, City of Now York, 123 F.3A 707 (2A Cir. 1997).

177 Mathers of Eldrige, 424 U.S. 319,335 (1976).

178 Full consideration of all such elements is beyond the scope of this paper.

179 The minimal the process provisions of A $3207 / \mathrm{S} .185$ contrast starkly with the extensive safeguards atforded the mentally ill when committed imoluntarily to a mental hospital in $\mathrm{NY}$ under Article 9 of the Mental Hygiene Law. 
180 Annas, rupra note 105 , at 1338.

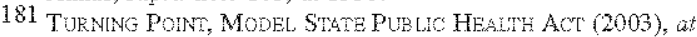
182 Id. at 1 .

http://www.tumingpointprogram.org/Pages/MSPHAfinal.pdf (last visited May 4, 2005).

183 See $i d$, arts. $v$ (Public Health Authorities/Powers), vI (Public Healh Emergencies), VII (Administrative Procedures, Civil and Criminal Enforcement, and Immunities).

184 See, e.g., id. $\$ \$ 5-108$ (b) (defining conditions and principles for quarantine and isolation, including requirements for the least restrictive means necessary, regular monitoring of individuals, immediate termination when an indi... vidual no longer poses a risk), (d)-(f) (elaborating procedures for isolation and quarantine with and without notice and hearing, and relief therefrom), 5-109(h) (disting four exceptions to required vaccination), 6-105(b) (providing for immunity for non-state actors assisting the state from civil liability for death or personal injury except for gross negligence or willul misconduct), 8-104 (specifying criminal penalties to which state actors are subject), 8-105 (specifying civil remedies available against state actors), 8-107(a) (providing for immunity for state actors from liability for death or personal injury except for gross negligence or willful misconduct).

185 Listed supra in text of paragraph following n.178.

186 Misrahi, supra note 80 , at 201. 


\section{Brographues of Partichanats}

\section{David M. Ackman}

David M. Ackman, MD, MPH, Nassan County Commissioner of Health joined the Health Department on January $29,2001$.

Most of Dr. Ackman's career has been spent in public health. After a year as a special assistant for medical affairs with the New York City Health and Hospital Corporation, he joined the CDC's Epidemic Intelligence Service, where he was assigned to the New York State Department of Health for two years. Finishing his assignment at the CDC, Dr. Acknan remained with the New York State Department of Health an additional three and a half years, including one and a half years as director of the Bureau of Communicable Disease Control. Most recently, Dr. Ackman was assistant medical director for the Sunset Park Family Health Center Network in Brooktyn, and a medical director at IPRO in Lake Success.

Dr. Ackman graduated from Wesleyan University in 1984 and received his MD from SUNY Health Science Center in Brooklyn in 1989. He received his MPH at Columbia School of Public Healih in 1998.

\section{Burbara Asheld}

Barbara Asheld, Esq, is a 1977 graduate of Albany Law School. She was an attoney with the predecessor to the Mental Hygiene Legal Service in the $2 d$ and $3 d$ Departments from 1977 to 1981 . She joined the New York State Department of Health Division of Legal Affairs in 1981. She has served there, variously, as senior attorney, associate attorney, acting counsel to the State Board for Professional Medical Conduct and director of the Burean of Honse Connsel.

\section{Michael Ralboni}

Michael Balboni emerged as the New York State Senate's leader on homeland security issues following the terrorist attacks of September 11, 2001.

Senator Balboni chairs the Senate's Committee on Veterans, Homeland Security, and Military Affairs, which oversees and passes legislation relating to all aspects of homeland security and emergency preparedness. This includes state and local emergency plaming; biological and chemical terrorism; computer and information technology security; agricultural terrorism; and other terrorism-related crimes.

Although Senator Balboni's homeland security profile increased after $9 / 11$, his interest in those issues long preceded that day. He was asked in 1999 to brief his colleagues on New York City's water supply and its vulnerability to terrorist attack. What he learned when researching the issue stunned him - and led to his authorship of the Senate's first bill on weapons of mass destruction later that year.

That bill defined weapons of mass destruction, and made it a crime to manufacture and/or possess a weapon of mass destruction. He also sponsored a bill that defined terorism and created penalties for terrorist acts. Both bills passed the Senate in mid-2001, months before the terrorist attacks.

Shortly after $9 / 11$, Senator Balboni sponsored what is now the state's anti-terrorism law. It creates severe criminal penalties for people who commit terrorist acts, make terrorist threats, or render assistance to terrorists in the state. He also authored a 2002 law that requires all water suppliers in 
the state to provide an analysis of vulnerability to terrorist attacks as part of their overall water emergency plan.

Since he becane chair of the Homeland Security Committee in January 2003 , he shepherded more than 20 anti-terrorism bills through the Senate. He also spearheaded several anti-terrorism measures that became law that:

- Make it a crime to possess or use a biological or chemical weapon.

- Create new penalties for crimes against nuclear facilities.

- Establish new crimes for money laundering for terrorism.

- Require chemical plants to undergo vulnerability assessments.

- Require local disaster preparedness plans to include plaming for a terrorist attack.

- Establish, in state law, the New York State Office of Homeland Security.

- Tighten the sale of ammonium nitrate, which is used to make fertilizer bombs.

In August 2005, Senator Balboni was appointed co-chaiman of the Executive Task Force on Homeland Security of the National Conference of State Legislatures (NCSL). He also is a member of the NCSL Executive Board and chairs the group's Law and Criminal Justice Committee. In addition, Senator Balboni is a 2005 senior fellow of the Homeland Security Policy Institute and a member of the federal National Citizen Corps Conncil.

In March 2004, then-Federal Homeland Security Secretary Tom Ridge appointed Senator Balboni to a national Task Force that examined the flow of homeland security dollars from the federal govermment to local communities. In addition to work on that Task Force, Senator Balboni served as cochair of the State Legislature's Temporary Joint Legislative Committee on Disaster Preparedness and Response, a bipartisan initiative involving both the state Senate and Assembly. He is also a member of the Senate Task Force on State and Local Emergency Preparedness, and in 2005 was appointed to the Statewide Wireless Advisory Council.

Elected to the New York State Senate in 1997, Senator Balboni is now serving his fifth tem. He represents the 7 th Senate District, which is located in northwestern Nassau County on Long Island. Before that, he served as a state Assemblyman from that area for almost eight years.

Senator Balboni graduated with honors from Adelphi University in 1981, and earned his Juris Doctor from St. John's University School of Law in 1984. Upon admission to the bar in 1985, he began his career in public service as counsel to former Senator John R. Dume. Senator Baboni was then connsel to the New York State Senate Judiciary Committee and connsel to the deputy majority leader of the Senate. In 1987, he was appointed deputy county attorney in Nassan County, where he served until his election to the State Assembly.

\section{Benjamin Berkman}

Benjamin Betkman is the Sloan Fellow in Bioterrorism Law and Policy at Georgetown University Law Center and the Center for Law and the Public's Health. In this capacity, Mr. Berkman has been examining the federal role in bioterrorism preparedness. He is spearheading the center's prodnction of a detalled proposal to reform and modernize federal public health powers, with the goal of ensuring that the federal govermment has the necessary powers in a public health emergency. This work is building on the center's work done on the Model State Emergency Health Powers Act. 
Mr. Berkman received a JD and an MPH from the University of Michigan Law School. Previously, he received a bachelor's degree in the history of science and medicine at Harvard University. Prior to joining the Center for Law and the Public's Health, Mr. Berkman worked for the American Medical Association Ethics Department, ABC News Medical Unit, and the Economic and Social Research Institute. Mr. Betkman studies a wide range of issues, focusing on bioterrotism, but also including mental health, genetics, organ donation, and medical malpractice tort reform.

\section{Robert L. Burhans}

Robert L.. Burbans is currently the New York State Department of Health's director of Public Health Preparedness and Response. Mr. Burhans oversees and coordinates the DOH's comprehensive allhazards preparedness and response activities, integration of local health departments, and the healthcare system in readiness activities. He oversees implementation of the CDC and Health Resources Services Administration Public Health Preparedness and Healthare Preparedness grants totaling \$45 million annually. In this role he is the department's primary preparedness liaison with other federal, state, and local agencies and key community partners. He also serves on the State Office of Homeland Security's Public Security Task Force. Mr. Burhans has over 27 years of pubic healh experience, including work at the local health department level, both as a member of a county health department and state district office; at the state health department regional office and central office program manager level; and most recently as an assistant division director, Division of Envirommental Health Protection in the Center for Envirommental Health. He previously served as the department's Preventive Health and Health Services Block Grant Coordinator, coordinating New York's annual application and performance report, and its administration of the $\$ 10$ million dollar grant.

Mr. Burhans has an AAS degree in Envirommental Technology and a BS in Biology.

\section{Linda L. Chezem}

Linda L. Chezem creates educational outreach opportunities between health related research, justice systems, and communities. Judge Chezem holds an appointment as professor, 4-H Youth, College of Agriculure, Purdue University, an adjunct appointment at the Indiana University School of Medicine in the Department of Medicine, and as an affiliated scholar with the Center for Public Health Law Partnerships at the University of Louisville, School of Medicine. Her current work effort is with the CDC Collaborating Center for Public Healh Law Partnerships at the University of Louisville and the National Institute on Alcohol Abuse and Alcoholism.

Linda L. Chezem served 22 years as a full-time judge in Indiana. Her first judgeship in a trial court was in Lawrence County, Indiana. She has been appointed as a special judge in over 300 cases serving 25 different counties. Her jurisdictional experience at trial court level ranged from traffic to felony-murder, marriage dissolution, probate, juvenile cases, and unimited civil and criminal dockets. In 1988, Judge Chezem was appointed to the Indiana Court of Appeals, Fourth District. She was retained on a statewide yes/no vote in 1992 .

Judge Chezem has focused on the improvement of adjudication through judicial education. In the course of these efforts Judge Chezem concluded that the abuse and dependence upon alcohol was the nexus of the single largest public health impact in the U.S. Her work includes service on the Indiana Judicial Conference Education Committee (chair: 1990-1993); American Bar Association, Judicial Administration Division, 1980-1999; National Council of Juvenile and Family Court 
Judges, 1982-1998, (Substance Abuse Training Committee: 1987-1993). During her appointment to a National Highway Traffic Safety Adrninistration Judicial Fellowship (1993-1995), Judge Chezem wrote The Inprovenent of the Adjudication of Driving under the Influence. After writing the manual for the instructor and the workbook for the students, Judge Chezem then assisted with the training of other judges to present the course in cooperation with the National Judicial College and the National Association of State Judicial Educators.

\section{Linda Fentiman}

Linda Fentiman is a professor at Pace Law School. She has practiced criminal law, enviromental law, and health law, and currently teaches criminal law, public health law, and health care organization, regulation, and financing. Prof. Fentiman has served on the faculties of Columbia and Suffolk University law schools and the University of Warsaw in Poland, where she was a Fulbright Scholar in 2003. She has written and presented on mental disability law issues, including the insanity defense and competency to stand trial; bioethical and health care access issues; issues of tele-health, including Internet pharmacies and telemedicine, and law school teaching via distance education. She is a fellow of the New York Academy of Medicine. She has been a consultant on law and ethics at Massachusetts General Hospital, has chaired the Committee on Health Law at the New York City Bar Association, and has been a member of the National Academy of Science Committee on Toxicogenomics. She is also a past chair of the AALS Section on Law and Mental Disability. Prof. Fentiman received a BS from Comell University, a JD from the State University of New York at Buffalo, and an LLM from Harvard University. She is admitted to the bar in California, New York, the District of Columbia, and Massachusetts.

\section{Richard $N$. Gottfried}

Richard N. Gotfried represents the 75 th Assembly District in the New York State Assembly, covering Chelsea, Clinton, Murray Hill, Midtown, and part of the Lincoln Center area in Manhattan. He is chair of the Assembly Health Committee. He is a leading state health policy-maker in New York and nationally.

Highlights of his legislative successes include:

- The Prenatal Care Assistance Program, Child Health Plus, and Family Health Plus;

- The Physician Profiling Law, which gives access to a doctor's record,

- The Healh Care Proxy Law, which allows people to designate an agent to make health care decisions for them if they lose that ability;

- Simplification of entollment in publicly-financed programs (such as Medicaid);

- Required health insurance to cover midwives" services;

- The landmark HIV Testing and Confidentiality Law

- Managed Care Reform;

- The Hudson River Park Act that established the park and protects the Hudson River", and the

- Creation of the Javits Convention Center and the 2005 law that expanded it.

In the Legislature, he has been the leading proponent of patient autonomy, especially in end-of-life care and reproductive freedom. Some of the important bills he sponsors are:

" "N.Y. Health" to create a universal publicly-funded health coverage plan for New York;

" "Right to Marry," which would allow same-sex couples to marry" 
- Family Health Care Decision Making, which establishes a process for health care decisions when a person is incapaciated and has not filled out a healh care proxy;

- Gender Non-Discrimination Act, which prohibits discrimination based on gender identity or expression (since 2003 ); and

- the bill to legalize the use of medical marijuana.

Each year, he fights to protect and increase funding for Medicaid, school health clinics, AIDS services, and other health concerns.

Assemblyman Gottfried is a member of the Assembly Democratic Steering Committee and the committees on Rules and Higher Education as well as Health. He is head of the Manhattan Assembly Democratic Delegation. He is a leading advocate in the Legislature for civil liberties, reproductive freedom, and gay rights. He has been repeatedly named to the New York Civil Liberties Union's Honor Roll. He was named "Environmental Legislator of the Year" by Environmental Advocales, and has been honored by Family Planning Advocates three times.

Mr. Gottried was the author of legislation to provide legal services for the disabled, strengthen the criminal laws against hazardous waste violators, strengthen Small Claims Court, prevent illegal evictions, and reform the J-51 tax exemption program. He was a pioneer in enacting legislation to recognize and protect the rights of crime victims. He was an architect of the 1978 Omnibus Crime Act and wrote laws to reform the grand jury system, strengthen the rape laws, and decriminalize marijuana. He drafted the Juvenile Justice Reform Act of 1976 and sponsored revisions of the laws on foster care, adoption, and child abuse.

He previously served as deputy majotity leader; assistant majority leader; chair of the Assembly committees on Codes (covering the criminal justice system), and Childen and Families, and chair of the Assembly task forces on the Homeless, Campaign Finance Refom, and Crime Victims.

Mr. Gottried was first elected to the Assembly in 1970, at the age of 23 , while a student at Columbia Law School. He is a graduate of Stuyvesant High School, Conell University (BA, 1968), and Columbia Law School (JD, 1973). He is a lawyer, but does not maintain a private practice. He works full time as a legislator. He is a fellow of the New York Academy of Medicine, and a member of the American Public Health Association, the New York Civil Liberties Union, the New York City Bar Association, the Stephen Wise Free Synagogue, the Arts Students League, and the China Institute.

\section{Robent G. M. Keating}

Robett Keating is the founding dean of the New Yotk State Judicial Institute. After receiving his law degree from Duke University, he entered the legal field as a trial attomey for the Legal Aid Society, and later began working at the District Attorney's Office in Brooklyn, eventually rising to the position of chief assistant district attorney. Judge Keating was the coordinator of criminal justice for Mayor Edward Koch, later being appointed to the Criminal Court bench in New York City and serving as supervising judge for Brooklyn and Staten Island. After being named the administrative judge for the New York City Criminal Court in 1984, he supervised and developed the Midtown Community Court, which has been recognized by several national organizations for its innovative solutions in justice, and inangurated the first drug altemative to prison program with the Brooklyn District Attomey's Office. He was designated a Court of Claims judge in 1987 and later became the administrative judge for the Supreme Court for Brooklyn and Staten Island. Judge 
Keating also has worked in the private sector, as a partner in a law firm, as senior executive vice president of a physician practice management company, and as chairman and CEO of a fim that provided consulting and alternative dispute resolution services. He is the current vice chair of the Mayor's Advisory Committee on the Judiciary and serves on the board of directors for the Fund for the City of New York and the Citizens Union of the City of New York.

\section{David Keepnews}

David Keepnews is director of the Office of Policy Development for The New York Acadeny of Medicine, where his work focuses on advancing and implementing evidence-based approaches to health policy and providing analysis of emerging policy issues.

Dr. Keepnews holds degrees in nursing, public health, law, and social policy. Prior to joining the staff of the New York Academy of Medicine in 2004, Dr. Keepnews was on the faculty of the School of Nursing at the University of Washington in Seattle, where he also held appointments in the School of Law and the Department of Health Services of the School of Public Healih and Community Medicine. He is currently an adjunct faculty member of the New York University College of Nursing and the University of Washington School of Nursing and School of Law.

Previously, Dr. Keepnews has served as director of policy for the American Nurses Association in Washington, DC, as regulatory policy specialist for the Californa Nurses Association and as an assistant regional counsel for the U.S. Department of Health and Human Services, Region IX, in San Francisco. Dr. Keepnews has also practiced as a registered nurse in mental health and substance abuse settings in San Francisco and New York. A fellow of the American Academy of Nursing, Dr. Keepnews serves as editor of Policy. Politics \& Nitsing Practice, a quarterly, tefereed journal focusing on nursing and health policy issues.

\section{Joshat Lipsinan}

Joshua Lipsman has been commissioner of health for Westchester County since May 2000. Prior to that, Dr. Lipsman was executive director of GMHC in 1999, and prior to that, for seven and a half years he led the Alexandria, VA, department of health. He previously was the medical director and administrator of the city's system of public health clinics in Houston and a staff physician and community health director on the Pine Ridge Indian reservation. Dr. Lipsman received bis MD from the Albert Einstein College of Medicine and completed a family medicine residency at the St. PaulRamsey Medical Center in Minnesota. He holds an MPH from the University of North Carolina at Chapel Hill, School of Public Health. He is board certified in family medicine, and in public health and general preventive medicine. An active clinician, he also is a board member of AAPH and a trustee of the American Board of Preventive Medicine. Dr. Lipsman graduated from Pace Law School in December 2005.

\section{Irma S. Russell}

Ima Russell is a professor of law and director of the National Energy-Environmental Law and Policy Institute at the University of Tulsa College of Law. During the 2005-06 school year Prof. Russell was visiting professor of law at Pace University School of Law, where she taught administrative law, environmental justice and advanced professional responsibility. Prior to that she was a professor of law at the University of Memphis, School of Law, where she taught environmental law, natural resources, contracts, and professional responsibility. In practice, she represented parties in Superfund negotiations, govermmental entities, lenders, and other clients on issues involving the 
National Envirommental Policy Act, wetlands designation and site mitigation, the Clean Water Act. asbestos regulations, and other environmental issues. She is a member of the American Bar Association Standing Committee on Ethics and Professional Responsibility and the chair of the Strategic Response Committee of the ABA Section of Environment, Energy, and Natural Resonrces. She serves as the section liaison to the Association of American Law Schools and to the ABA Standing Committee on Ethics and Professional Responsibility. Prof. Kussell was the fonnding chair of the Memphis Bar Association Envirommental Law Section and served as chair of the Tennessee Bar Association Environmental Section. Her legal publications include a book, Iswes of Legal Ethics in The Practice of Environmental Law, articles, essays, and chapters on issues of legal ethics, envirommental justice, modification of contracts, and pedagogy. Prof. Russell received her JD from the University of Kansas, School of Law in 1980. She served as judicial clerk to the Honorable James K. Logan on the U.S. Court of Appeals for the Tenth Circuit. She is a member of the American Law Institute, the Tenth Judicial Circuit Conference, the Temessee Bar Association, and the American Bar Association. She is admitted to the bars of Kansas, Missouri, and Tennessee.

\section{Mark R. Shalman}

Mark R. Shulman is assistant dean for graduate programs and international affiliations and adjunct professor of law at Pace. During the 2005-06 academic year he was also a visiting scholar at Yale University's International Security Studies Program. He is a member of the board of divectors of the Asian University for Women Support Foundation (antil January 2006), Nexi Generation Nepal, and the Association of the Columbia Joumal of Transnational Law. Until 2003, he practiced comporate law at Debevoise \& Plimpton. Immediately prior to joining Pace, he established and directed the Worldwide Security Program at the EastWest Institute. Mr. Shulman has also served on the faculty at Yale, the US Air War College, and at Columbia University's schools of law and of international and public affairs. He has published widely in the fields of history, law, and security affairs. His books include Navalism and the Emergence of American Sea Power 1882-1893 (1995), The Laws of War: Constraints on Worfare in the Westert Wortd (1994), and The Imperiat Fresidency and the Consequences of 9/11: Lawyers Respond to the Global War on Terrorism (2007). He graduated from Yale (BA), Oxford (MSt), the University of California, Berkeley (PhD, history), and Columbia Law School (JD) where he served as editor-in-chief of the Columbia Jormal of Thanshational Law. Mr. Shulman was recently appointed chair of the International Human Rights Committee of the New York City Bar Association.

\section{Victor W. Sidel}

Victor W. Sidel is the Distinguished University Professor of Social Medicine at the Montefiore Medical Center and the Albert Einstein College of Medicine.

After graduating from Princeton University with honors in physics and from Harvard Medical School with honors in biophysics, Victor Sidel was trained in internal medicine and public health at Harvard, the National Institutes of Health, the Centers for Disease Control and Prevention, and the London School of Hygiene and Tropical Medicine. He headed the Community Medicine Unit at Massachusetts General Hospital from 1964 to 1969 and then moved to the Bronx to chair the Deparment of Social Medicine at Montefiore Medical Center and the Albert Einstein College of Medicine. He was appointed distinguished university professor of social medicine at Montefiore and Einstein in 1984. Since 1973 he has been chair of the Institutional Review Board for Protection of Human Subjects in Research at Montefiore. Dr. Sidel is also adjunct professor of public health and a member of the Division of Medical Ethics at Weill Medical College of Comell University. 
Dr. Sidel has served as president of the American Public Health Association and of the Public Health Association of New York City, and as a member of the national Board of Directors of Physicians for a National Health Program. He was the honorary Cleveringa Professor of Medicine and Human Rights at Leiden University in the Netherlands in 1998-1999. He has spoken widely on public health, on medical and public health ethics, and on problems in health care in the United States and other conntries.

Dr. Sidel was one of the founders of Physicians for Social Responsibility and of the International Physicians for the Prevention of Nuclear War, the recipient of the 1985 Nobel Prize for Peace. He has been elected president of both organizations and has spoken and published widely on the economic, social, environmental, and health consequences of the arms race; on the risks posed by the proliferation of nuclear, chemical, and biological weapons; on the diversion of resources and the curtailment of human rights entailed in war and preparation for war; and on unbalanced responses to the perceived threat of terrorism.

\section{Andrew J. Spano}

Andrew J. Spano became Westchester's seventh county executive on January 1, 1998. Mr. Spano is the second Democrat to be elected to the connty's highest office. He is also president of County Executives of America, an organization representing the interests of counties nationwide. As county executive, Mr. Spano has initiated dozens of programs to improve the quality of life in Westchester and enhance the security and safety of all county residents.

Long before Sept. 11, 2001, the Spano administration began focusing on improving programs to protect its residents from threats, whether they involve terrorist attacks or natural disasters. In 2000 , under his leadership, the county created the Department of Emergency Services to overhaul the counly's troubled fire training center. The department now coordinates fire, emergency management and emergency medical services. At its Valhalla facility, il provides dispatching services for fue and EMS providers and a first-rate fire and emergency training center used by personnel from counties thronghout the metropolitan area. Under Mr. Spano, the connty developed an All Hazards Emergency plan that coordinated separate plans over the years to deal with crises including natural disasters, problems at Indian Point, and health emergencies.

Westchester sought out and received federal monies to deal with bioterrorism and health emergencies, creating programs to coordinate, train, and improve communications among the county's various hospitals and emergency service providers. The county recently obtained radio frequencies that will allow police and fire agencies from different jurisdictions to commumicate in an energency. Westchester's lab was recently upgraded to a Level III, one of only four in the state allowing it to do on-the-spot testing in the event of chemical or biological terrorism.

A strong, tireless advocate for people, Mr. Spano likes nothing better than getting "out thete" to talk and listen to his constituents. He has worked to make govermment more accessible through the county's award-winning website and through "Westchester Telecom," a high-speed fiber optic network that links schools, libraries, local govermments, and oher public institutions.

Before coming to government, Mr. Spano spent 25 years in public education where he distinguished himself as a teacher, counselor, and administrator, serving children with special needs. He was one of the founders of the United Federation of Teachers in New York City. 
He has also been the recipient of numerous awards in the areas of human rights, education, government, and labor. Some of these include: an honorary doctorate in commercial affairs awarded by Pace University in 2004; the O'Hare Medal awarded by Fordham University's School for Social Justice in 2005; the Westchester Arts Council's 2000 "Man of the Year" award; the 2000 League of Conservation Voters award, the 1999 Guardian of the Sound award for environmental protection of the Long Island Sound; the Fight Hunger Award from the Westchester Coalition of Food Pantries and Soup Kitchens; and the Special Achievement Award from the New York State Federation of Police. Mr. Spano holds bachelor's and master's degrees from Fordham University.

\section{Barry Steinhardt}

Barry Steinhardi is director of the ACLU's Technology \& Liberty Project, a position he has held since 2002. He was the associate director of the American Civil Liberties Union between 1992 and 2002, and has served as executive ditector of the Vermont and Pennsylvania affiliates of the ACLU.

Mr. Steinhardt has been a prominent advocate for privacy and civil liberties, and has led a variety of activities aimed at shedding light on relevant issues, combating flawed rules and legislation, and empowering individual activism. In addition to testifying before the U.S. Congress, he has addressed the National Conference of State Legislatures, the National Commission on the Future of DNA Evidence, the Hoover Institute, and the UNESCO Conference on Intellectual Property. At the invitation of members of the Japanese Parliament, he gave a series of lectures in Japan on electronic survellance in the information age. His essays have appeared in a number of publications including USA Today, CIO Magazine, and the joumal of the Davos World Economic Forum.

Mr. Steinhardt was chair of the 2003 Computer Freedom and Privacy Conference and a cofounder of the Global Internet Liberty Campaign, the world's first international coalition of Non-Governmental Organizations concemed with the rights of Internet users to privacy and free expression. He was also a member of the Blue Ribbon Panel on Genetics of the National Conference of State Legislaures, and the U.S. delegation to the G-8 Govermment and Private Sector Tokyo conference on Cyber Crime. In 1998, Mr. Steinhardt took a leave of absence from the ACLU to serve as president of the Electronic Frontier Foundation. Currenty, he is on the Advisory Panel for Genetic Services to the State of Washington Department of Health, and the Advisory Committee to the U.S. Census.

Barry Steinhardt is a 1978 graduate of the Northeastern University School of Law. 


\section{PUBLIC HEALTH AND THE LAW: RESPONDING TO TERRORISM AND OTHER PUBLIC HEALTH EMERGENCIES IN NEW YORK}

November 30,2005

Welcome and Introduction

$8: 50$ a.m. $-9: 20$ a.m.

Welcome, Hon. Robert Keating, Dean, New York State Judicial Institute

Conference Charge, Irma Russell, Visiting Professor, Pace Law School

Introdtction, Dr, Joshua Lipsman, Westchester County Health Commissioner

Session I:

The Threats

Moderator: Dr. Joshua Lipsman, Westchester County Health Commissioner

9:20) a.m. - $10: 45$ a.m.

The Politics of Piblic Health Energencies, Hon. Andrew Spano, Westchester Connty Executive Rishs and Impact of Public Health Emergencies, Dr. Victor W. Sidel, Distinguished University Professor of Social Medicine, Montefiore Medical Center and Albert Einstein College of Medicine

Emergencies and Civit Liberties, Barry Steinhard, Director of Technology and Liberly, American Civil Liberties Union

Session II:

The Institutions

Modefator: Prof, Linda Fentiman, Professor of Health Law, Pace Law School

$11: 00$ a.m. $-12: 3010 . m$.

Infrastructure, Dr. David Ackman, Nassau County Health Commissioner

Medicat Institutions, Dr. David Keepnews, Director, Office of Policy Development, New York Academy of Medicine

Judiciary, Judge Linda Chezem, Special Assistant, Office of the Director, National Institute on Alcohol Abuse and Alcoholism

Lunchean

$12+30$ p.m. $-2 * 00$ p.m.

Session III:

Siate and Federal Public Heall Law Intiatives

Modentor, Prof. Linda Fentiman, Professor of Health Law, Pace Law School 
$2.040 \mathrm{p} . \mathrm{m} .-3.30 \mathrm{p} . \mathrm{m}$.

New York Law Today, Robert Burhans, Director, New York State Office of Public Health, Preparedness and Response to Bioterrorism

New York Law, Barbara Asheld, Associate Attomey, New York State Department of Health

Thwhing Point Model Act, Benjamin Benkman, Sloan Fellow, Georgetown University Law Center

Session IV:

Where are we going?

Moderator, Mark R. Shulman

3:40 p.m. - 5:00 p.m.

Proposed Legistation, Assemblyman Richard Gothried, Chair, New York Assembly Health Committee

Proposed Legislation, Senator Michael Balboni, Chair, New York Senate Committee on Veterans, Homeland Security and Military Affairs

Closing Remaprs, Mark R. Shulman, Symposium Chair and Assistant Dean and Adjunct Professor, Pace Law School

\section{Reception}

5:00 p.m. $-7: 00$ p.m. 


\section{Pace Law School}

Currently celebrating the thirtieth anniversary of its establishment, Pace Law School is a New York law school with a suburban campus in White Plains, NY, 20 miles north of New York City. The school offers the JD program for full-time and part-time day and evening students. Its postgraduate programs include the LLM and SSD degrees in environmental law and the LLM in comparative legal studies. Pace has one of the nation's top-rated environmental law programs, and its clinical education program is nationally ranked, offering clinics in domestic violence prosecution, entironmental law, securities arbitration, criminal justice, and disability rights. This symposium is a project of Pace Law School's renowned health law program. www law pace.edu.

Pace is a comprehensive, independent university with campuses in New York City, Pleasantville, and White Plains, NY, and a Hudson Valley Center at Stewart International Airport in New Windsor, NY. More than 14,000 students are enrolled in undergraduate, graduate, and professional degree programs in the Dyson College of Arts and Science, the Lubin School of Business, the Ivan G. Seidenberg School of Computer Science and Information Systems, the Lienhard School of Nursing, and Pace Law School. www.pace.edu. 